\title{
25 Years Scientific Research Center of Medical Biophysics Scientific Research Project and Publications from 1996 to 2021
}

\author{
Ignat Ignatov \\ DSc, Professor, Scientific Research Center of Medical Biophysics (SRCMB), \\ N. Kopernik Street, 32, Sofia 1111, Bulgaria
}

\begin{abstract}
The Scientific Research Center of Medical Biophysics (SRCMB) carries out studies in the following directions - structure of water, origination of life and living matter, mountain water and longevity, high frequency color coronal discharge, nanotechnologies, astrobiology, biological effects in heavy water, entropy and time in living matter, visual analyzer, biophysical fields, biotechnologies, shungite. Scientific Board of SRCMB - Prof. Dr. Ignat Ignatov DSc (Director), Prof. Christos Drossinakis (Honorable Director), Lieselotte Eder (Deputy Director), Alexander Ignatov (manager), Dr. Igor Akszjonovics MD (Deputy Director), Prof. Stanislav Zenin, Dipl. Eng. Enrico Bauer, Dipl. Eng. Chavdar (Charlie) Stoyanov, Paul N. Kleindienst, Heide Trautwein (Deputy Director), Teodora Todorova (web designer), Tanya Metodieva, Polya Ivanova, Daniya Nachkova, Verka Nikolova (Master in Mathematics), Svetla Damyanova (Master in Pharmacy), Gergana Genova, Maria Abazova (Bachelor in Medicine), Dipl. Eng. Erwin Lehki, Dipl. Eng. Tsolo Petkov, Dipl. Eng. Hristo and Silvia P. Deneva.

Keywords:longevity, mountain water, origination of life and living matter, high frequency color coronal discharge, nanotechnologies

DOI: $10.7176 / \mathrm{JHMN} / 88-06$

Publication date: April $30^{\text {th }} 2021$

1. Introduction

In Scientific Research Center of Medical Biophysics (SRCMB)

\section{Materials and Methods}

The author methods are: NES and DNES Spectral Analysis (Antonov, 1990; Antonov, Ignatov. 1998) and Color coronal gas discharge spectral analysis (Ignatov, 2007)

\subsection{NES and DNES Spectral Analysis}

The device for DNES spectral analysis was made by A. Antonov on an optical principle. For this was used a hermetic camera for evaporation of water drops under stable temperature $\left(+22-24{ }^{\circ} \mathrm{C}\right)$ conditions. The water drops were placed on a water-proof transparent pad, which consists of thin maylar folio and a glass plate. The light was monochromatic with filter for yellow color with wavelength at $\lambda=580 \pm 7 \mathrm{~nm}$. The device measures the angle of evaporation of water drops from $72.3^{\circ}$ to $0^{0}$. The DNES-spectrum was measured in the range of $-0.08-$ $0.1387 \mathrm{eV}$ or $\lambda=8.9-13.8 \mu \mathrm{m}$ using a specially designed computer program. The main estimation criterion in these studies was the average energy $\left(\Delta \mathrm{E}_{\mathrm{H}} \ldots \mathrm{O}\right)$ of hydrogen $\mathrm{O} \ldots \mathrm{H}$-bonds between $\mathrm{H}_{2} \mathrm{O}$ molecules in water samples and human blood serum.
\end{abstract}

\subsection{Color coronal gas discharge spectral analysis}

Experiments were carried out by using selective high-frequency electric discharge (SHFED) on a device with the electrode made of polyethylene terephthalate (PET, hostafan) with an electric voltage on the electrode $15 \mathrm{kV}$, electric impulse duration $10 \mu \mathrm{s}$, and electric current frequency $15 \mathrm{kHz}$. The electrode of the device was made of hostafan, and was filled up with electro-conductive fluid. The spectral range of the emission was in the range $380-495 \mathrm{~nm}$ and $570-750 \pm 5 \mathrm{~nm}$. The measurements were measured in electron-volts $(\mathrm{eV})$. Detection of gas disharge glowing was conducted in a dark room equipped with a red filter. On the electrode put a photosensitive paper or color film. The object under study (human thumb) was placed on top of a sheet of photo paper or color film. Between the object and the electrode were generated impulses of the electric voltage $15 \mathrm{kV}$ and electric current frequency $-15-24 \mathrm{kHz}$; on the reverse side of the electrode was applied the transparent electrically conductive thin copper coating. Under these conditions in the thin contact gas space between the studied object and electrode was generated gas electric discharge in the form of characteristic glow around the object - a corona gas electric discharge in the range of $280-760 \mathrm{~nm}$, illuminates a color photo or a photographic film on which was judged about the bioelectric properties of the studied object. Along with the visible range, for this method were obtained color spectra in UV and IR range. Evaluation of the characteristic parameters of snapshots was based on the analysis of images treated by standard software package. Statistical processing of the experimental data was performed using the statistical package STATISTISA 6 using Student's $t$-criterion (at $\mathrm{p}<$ 
$0.05)$.

\section{Results and Discussions}

Scientific research projects executed by Prof. Ignat Ignatov and the team of the Scientific Research Center of Medical Biophysics

2009

Spectral analysis of various types of water.

Funding: Natural persons from Switzerland, Germany, Austria and Bulgaria.

2010

Research of the spectrum and composition (Eurotest control) of four mountain springs in Teteven. The springs are "Dolna Cheshma", "Gorna Cheshma", "Klindiovo" and "Sonda".

Funding: Self-financing and Teteven Municipality

Information boards at the springs placed by Teteven Municipality.

Research related to the model for the origin of life and living matter in hot mineral water.

Funding: Teteven Municipality, natural persons from Switzerland, Germany and Bulgaria.

2011

Study of "Devin" mineral and spring water and "Divna" table water.

Funding: Devin AD.

2012

Pilot study of longevity factors in the municipalities of Teteven, Yablanitza and Ugarchin, Lovech district.

Funding: Aquachim JSK (Assoc. Prof. Borislav Velikov); Natural persons from Switzerland, Germany, Austria, Russia and Bulgaria.

2013

Pilot study of longevity factors in the municipalities of Teteven, Yablanitza and Ugarchin, Lovech district.

Funding: Aquachim JSK (Assoc. Prof. Borislav Velikov); Natural persons from Switzerland, Germany, Austria, Russia and Bulgaria.

2014

Study of longevity factors in Dolni Dubnik municipality, Pleven district.

Funding: Aquachim JSK (Assoc. Prof. Borislav Velikov), Bulgarian Society for Activated Water (Eng. Atanas Atanasov); Natural persons from Switzerland, Germany, Austria, Russia and Bulgaria.

2015

Study of factors of longevity in Lukovit, Lovech district

Funding: Aquachim JSK (Assoc. Prof. Borislav Velikov)

Study of factors of longevity in Kuklen and Rodopi municipalities, district Plovdiv

Funding: Eco Hotel Zdravec (eng. Todor Burdzhiev)

Research of mountain and melt water from Glacier Rosenlaui, Swiss Alps

Funding: Vortex Power AG (Alexander Class, Matthias Mend, Peter Zuecker)

Scientific Research projects that are being implemented at present by Prof. Ignat Ignatov and the team of the Scientific Research Center of Medical Biophysics

2015

Forums where the project results are presented

2016

Research of Glacier Water from Andes, Chile

Funding: Alfonso and Pablo Bianchini

Research of Mountain Sources in Teteven and Sources with Mineral Water, village of Golyam Izvor,

Municipality of Teteven

Funding: Municipality of Teteven (mayor Dr. Madlena Boyadzhieva)

Research of the products of the company Lava Vitae, Austria

2017

Research of Zeolite water Sevtopolis

Funding: Company for production of Zeolite water Sevtopolis

Research of three spring mountain waters from Romania

Funding: Aqua Benefica Cristalia SR, Alexandru Raducanu

Research of Colostrum, Moringa and Blueberry juice

Funding: Anti aging, Franziska Achleitner, Graz, Austria

Research of Austrian cleaners for water Изследване на австрийски пречистватели за вода

Funding: Aqua-Vit, Pock-Vital-System, Peter Pock, Graz, Austria

Programs for detoxification

Funding: Medical Center Oxylife-Sofia 
Research of Bulgarian Zeolite

Funding: Rhodosorb

2019

Research of food supplement CortiNon+

Funding: IdeaLabs, LLC, USA

Research of the device for water WaterDiam

Funding: WaterDiam, France

Research of the device for water Sosei Water

Funding: Sosei Water, Japan

2020

Research of food supplement Pyrocet

Fundinge: IdeaLabs, LLC, USA

Research of food supplement Oxidal

Funding: IdeaLabs, LLC, USA

Research of the device for water EVOdrop

Funding: EVOdrop, Sweden

Project of European Union. Support for micro and small enterprises to overcome the economic consequences of the COVID-19 pandemic

Scientific Research projects that are being implemented at present by Prof. Ignat Ignatov and the team of the Scientific Research Center of Medical Biophysics

Forums where the project results are presented

22 March

World Water Day

Scientific Research Center of Medical Biophysics

Teteven municipality

\section{June}

Days of Mountain Water and Healing Tourism

Scientific Research Center of Medical Biophysics

Teteven

International Conference "Physics, Chemistry, Biology of Water"

USA, 2012

Euromedica

Hanover, Germany

World Demographic and Aging Forum

St. Gallen, Switzerland

\section{Conclusion}

The results and projects are object of 480 publications.

\section{References:}

1. Ignatov, I., Antonov, A., Galabova, T. (1998) Medical Biophysics - Biophysical Fields of Man, Gea Libris, Sofia.

2. Ignatov, I., Antonov, A., Galabova, T. (1998) Medical Biophysics - Biophysical Fields of Man, First World Congress for Global Health, EWEI, Manila.

3. Ignatov, I., Antonov, A., Galabova, T., Stoyanov, S. (2001) Self-organization and "Informationability" of Water, Their Importance for the Possible Processes of Structuring of the Living Matter, Seminar "Man and Nature", (SRCMB), Sofia, Teteven, pp. 63-65.

4. Ignatov, I., Antonov, A., Galabova, T., Avramov, K. (2001) The Total Solar Eclipse on 11 August 1999 and Research by Biophysical Model Systems, Seminar "Man and Nature", (SRCMB), Sofia, Teteven, pp. $42-44$.

5. Ignatov, I., Antonov, A., Galabova, T. (2001) Structural Alterations in Water Due to the Earth Ground Radiation, Seminar "Man and Nature" (SRCMB), Sofia, Teteven, pp 55-57.

6. Ignatov, I. (2005) Energy Biomedicine, Origin of Living Matter, "Informationability" of Water, Biophysical Fields, Gea-Libris, Sofia.

7. Ignatov, I. (2006) Energy Biomedicine, Origin of Living Matter, "Informationability" of Water, Biophysical Fields, Gea-Libris, ENIOM, Sofia, Moscow.

8. Ignatov, I. (2007) Energy Biomedicine, Origin of Living Matter, "Informationability" of Water, Biophysical Fields, ICH, Munich. 
9. Ignatov, I. (2007) There are not Reliable Results with Research with Infrared Spectroscopy of Homeopathic Solutions after Avogadro’s Number, Ministry of Health, Moscow, pp 196-199.

10. Marinov, M., Ignatov, I. (2008) Color Kirlian Spectral Analysis. Color Observation with Visual Analyzer, Euromedica, Hanover, pp 57-59.

11. Ignatov, I. (2010) Which Water is Optimal for the Origin (Generation) of Life? Euromedica, Hanover, pp 34-37.

12. Ignatov., I., Nikolova, V. (2010) Healing Tourism - Dream or Reality. Mountain Water - "Force" for Life, Days of Mountain Water and Healing Tourism, Teteven, Bulgaria, Euromedica, Hanover, pp. 42-44.

13. Ignatov, I. (2011) Entropy and Time in Living Organisms, ArchivEuromedica, Hanover, 1st\&2nd Edition, pp. 74-75.

14. Ignatov, I. (2011) Entropy and Time in Living Organisms, Euromedica, Hanover, pp. 60-62.

15. Ignatov, I., Antonov, A., Galabova, T., (2002) Scientific Research Studies with Christos Drossinakis (October 2001 - October 2002), Int. Conference "Man and Nature", SRCMB, Sofia.

16. Ignatov, I., Tsvetkova, V. (2011) Water for the Origin of Life and "Informationability" of Water, Kirlian (Electric Images) of Different Types of Water, Euromedica, Hanover, pp. 62-65.

17. Mosin, O. V., Ignatov, I. (2011) Structure of Water and Physical Reality, Consciousness and Physical Reality, Natural Science, Moscow, Vol.17, No. 9, pp. 16-31.

18. Mosin, O. V., Ignatov, I. (2011) Water - Substance of Life, Consciousness and Physical Reality, Natural Sciences, Moscow, Vol.17, No. 11, pp. 9-21.

19. Mosin, O. V., Ignatov, I. (2012) Isotopic Effects of Deuterium in Bacteria and Micro-algae in Vegetation in Heavy Water $\mathrm{D}_{2} \mathrm{O}$, Water: Chemistry and Ecology, Moscow, No. 3, pp. 83-94.

20. Ignatov, I., Mosin, O. V., Naneva, K. (2012) Water in the Human Body is Information Bearer about Longevity, Naturopathy, Hanover, pp. 39-41.

21. Ignatov, I., Mosin, O. V., Naneva, K. (2012) Water in the Human Body is Information Bearer about Longevity, Euromedica, Hanover, pp. 110-111.

22. Mosin, O. V., Shvets, V. I, Skladnev, D. A., Ignatov, I. (2012) Studying of Microbic Synthesis of Deuterium Labeled L-Phenylalanin by Methylotrophic Bacterium Brevibacterium Methylicum on Media with Different Content of Heavy Water, Russian Journal of Biopharmaceuticals, Vol. 4, No 1: pp. 11-22.

23. Ignatov, I., Mosin, O. V. (2012) Hot Mineral Water with Deuterium Molecules for the Origin of Life and Living Matter, Congress Science, Information, Consciousness, Saint-Petersburg Technical University, pp. 137-149.

24. Ignatov, I., Mosin, O. V. (2012), Kirlian Effect for the Study of Properties of Water and Biological Objects, Congress Science, Information, Consciousness, Saint-Petersburg Technical University, pp. 150-157.

25. Mosin, O. V., Ignatov, I.(2012) Study of Water Clusters, Congress Science, Information, Consciousness, Saint-Petersburg Technical University, pp. 132-136.

26. Mosin, O. V., Ignatov, I. (2012) Composition and Structural Properties of Fullerene Analogious Mineral Shungite, Nanomaterials and Nanotechnologies, Moscow, No2, Science of Education, pp. 25-36.

27. Mosin, O. V., Ignatov, I. (2012) The Natural Photo-Transforming Material Bacteriorhodopsin Derived from Halobacterium Halobium, Nanomaterials and Nanotechnologies, Moscow, No2, Science of Education, pp. 47-57.

28. Ignatov, I. (2012) Origin of Life and Living Matter in Hot Mineral Water, Conference on the Physics, Chemistry and Biology of Water, Vermont Photonics, USA.

29. Ignatov, I. (2012) Water in Human Body is Informational Bearer about Longevity, Conference on the Physics, Chemistry and Biology of Water, Vermont Photonics, USA.

30. Mosin, O. V., Ignatov, I. (2012) Enigma of Ice Crystals, Consciousness and Physical Reality, Natural Science, Moscow, Vol. 17, No. 5, pp. 21-31.

31. Mosin, O. V., Ignatov, I. (2012) Adaptation in Heavy Water, Phonotypical or Genetic Phenomena, Consciousness and Physical Reality, Natural Science, Moscow, Vol. 17, No 4, pp. 25-36.

32. Mosin, O. V., Ignatov, I. (2012) Separation of Heavy Isotopes Deuterium (D), Tritium (T) and Oxygen $\left({ }^{18} \mathrm{O}\right)$, Consciousness and Physical Reality, Natural Science, Moscow, Vol. 17, No. 6, pp. 18-29.

33. Ignatov, I., Mosin, O. V (2012) Kirlian Effect for the Study of Properties of Water and Biological Objects, Consciousness and Physical Reality, Bioinformation, Moscow, Vol. 17, No. 8, pp. 23-34.

34. Mosin, O. V., Ignatov, I. (2012) Contemporary Analyses for the Structure of Water, Institute for Human Ecology and Sanitation of Environment "Sysihina", Moscow.

35. Mosin, O. V, Ignatov, I. (2012) Structure of Water, Chemistry, Moscow, No. 11, pp. 24-27.

36. Ignatov, I., Mosin, O. V (2012) Isotopic Composition of Water and its Temperature in Modeling of Primordial Hydrosphere Experiments, VIII Int. Conference Perspectives of the Development of Science and Technique, Biochemistry and Biophysics, Vol. 15, pp. 41-49.

37. Mosin, O. V, Ignatov, I. (2011) Separation of Heavy Isotopes Deuterium (D) and Tritium (T) and 
38. Mosin, O. V, Ignatov, I. (2012) Application of Fullerene Analogious Mineral Shungite in Construction Industry and Building Technologies, Nanotechnologies in Construction Industry, Moscow, No. 6, pp. 81-93.

39. Mosin, O. V, Ignatov, I. (2012) Studying of Isotopic Effects of Heavy Water in Biological Systems on Example of Prokaryotic and Eukaryotic Cells, Biomedicine, Moscow, Vol. 1, No. 1-3, pp. 31-50.

40. Mosin, O. V, Ignatov, I. (2012) Modern Technologies for Seawater Desalination, Energy Saving and Water Preparation, Moscow, No. 4, pp. 13-19.

41. Mosin, O. V, Ignatov, I. (2012) Enigma of Ice Crystals, Nature and Human, Moscow, No. 1-3, pp. 3032.

42. Ignatov, I., Ivanova, I. (1995) Anotomy and Physiology, Gea Libris, Sofia.

43. Ignatov, I. (2003) Objective Medical and Biophysical Evidence for Bioinfluence, part III, V International Congress, Folk Medicine of Russia - Past, Present, Future, ENIOM, Moscow, pp. 77-78.

44. Ignatov, I., Delinick, A. (2006) Research of Homeopathic Solutions, Conference in National Center for Public Health Preservation, Ministry of Health, Sofia.

45. Ignatov, I. (2006) Research of Homeopathic Solutions, Society of Greek Homeopaths' Conference, Athens.

46. Ignatov, I., Antonov A., Galabova, T., Stoyanov, S. (2000) Scientific Research Center of Medical Biophysics, Scientific and Practical Aspects of Popular Medicine, part I, IV International Congress, Folk Medicine of Russia - Past, Present, Future, ENIOM, Moscow, pp.164-165.

47. Ignatov, I., Tzaneva, P. (1999) Biostimulation of Ophthalmic Diseases, I Seminar "Man and Nature", SRCMB, Sofia, Ravadinovo, pp.16-18.

48. Shvets, V. I, Yurkevich, A. M., Mosin, O. V., Skladnev, D. A., Ignatov, I. (1997) Preparation of Deuterated Inosine Suitable for Biomedical Application, Conference Man and Nature, SRCMB, Sofia, pp. 23-24.

49. Karnaukhova, E. N., Mosin, O. V., Reshetova, O. S., Ignatov, I. (1996) Biosynthetic Production of Stable Isotope Labeled Amino Acids Using Methylotroph Methylobacilicus Flagelatum, Man and Nature, SRCMB, Sofia, pp. 28-36.

50. Mosin, O. V., Skladnev, D. A., Shvets, V. I, Ignatov, I. (1998) Biosynthesis of 2H-Labeled Phenylalanine by a New Methylotrophic Mutant Brevibacterium Methylicum, Man and Nature, SRCMB, Sofia, pp. 13-17.

51. Mosin, O. V., Egorova, T. A., Skladnev, D. A., Yurkevich, A. M., Shvets, V. I, Ignatov, I. (1999) Derived Bacteriorhodopsin Labeled with Stable Isotopes for the Amino Acid Residues of Aromatic Amino Acids, Man and Nature, SRCMB, Sofia, pp. 11-14.

52. Mosin, O. V, Ignatov, I. (2009) Shugite - Natural Nanothecnological Material, Man and Nature, SRCMB, Sofia, pp. 34-35.

53. Mosin, O. V, Ignatov, I. (2012) The Phenomenon of Cellular Adaptation in Heavy Water, XVIII International Conference Modern Problems of Humanities and Natural Sciences, Theory and Practice in Modern Science, Moscow. pp. 28-34.

54. Mosin, O. V, Ignatov, I. (2012) Mathematical Models of Water, XIII International Conference Modern Problems of Humanities and Natural Sciences, Moscow.

55. Ignatov, I., Mosin, O. V. (2012) Cellular Adaptation to Deuterium Oxide (2H2O), Euro-Eco, Hanover, 61.

56. Ignatov, I., Mosin, O. V. (2012) Isotopic Composition of Water and its Temperature in Modeling of Primordial Hydrosphere Experiments, Euro-Eco, Hanover, 62.

57. Ignatov, I. (2005) Energy Biomedicine, Frontier Perspectives, Vol. 14, No. 1, p. 44.

58. Ignatov, I. (2004) Objective Biophysical and Medical Evidence of Bioinfluence, MISAHA, No. 40-45, pp.4-5.

59. Mosin, O. V, Ignatov, I. (2012) The Photo-Transforming Photochrome Protein Bacteriorhodopsin Derived from Photoorganoheterotrophic Halobacterium Halobium, Nanotechnics, Moscow, Vol. 3, No. 31, pp. 68-74.

60. Mosin, O. V, Ignatov, I. (2012) Coronal Effect in Biomedicine Diagnostics and Research of Properties of Biological Objects and Water, Biomedical Radio electronics, Biomedical Technologies and Radio electronics, Moscow, No. 12, pp. 13-21.

61. Ignatov, I., Mosin, O. V.(2012) The Process of Perception of the Light and the Evolution of Higher Animals and Human, Consciousness and Physical Reality, Natural Science, Moscow, Vol. 17, No. 10, pp. 14-28.

62. Mosin, O. V., Ignatov, I. (2012) Biological Basis of Adaptation Bacteria in Heavy Water, Consciousness and Physical Reality, Natural Science, Moscow, Vol. 17, No. 11, pp. 18-30.

63. Mosin, O. V, Ignatov, I. (2012) The Composition and Structural Properties of the Fields in Russia of 
Fullerene Natural Mineral Shungite, Nanoengineering, Moscow, Vol. 18, No. 12, pp. 17-24.

64. Ignatov, I., Mosin , O.V. (2012) Process of Perception of Light and Evolution of View of Higher Animals amd Human, Consciousness and Physical Reality, Moscow, Vol. 18, No. 12, pp. 14-27.

65. Mosin, O. V, Ignatov, I. (2012) Deuterium Water Greatly Influenced the Development of Life? No. 6, Biology, SciLib.com.

66. Mosin, O. V, Ignatov, I. (2013) Biological Influence Deuterium on Cells of Different Microorganisms, Biology, Actual Scientific Developments, Moscow, Vol. 24, pp 81-86.

67. Mosin, O. V, Ignatov, I. (2012) Natural Fulleren Containing Mineral Sorbent Shungite in Water Treatment and Water Partification, Clean Water: Problems and Decisions, Moscow, No.3-4, pp. 109-115.

68. Mosin, O. V, Ignatov, I. (2012) Colloid Silver in Bionanotechnology, Biotechnosphere, SaintPetersburg, Vol. 23-24, No.5-6, pp. 49-55.

69. Mosin, O. V, Ignatov, I. (2012) Natural Photo-Transforming Material Bacteriorhodopsin Derived from Halobacterium Halobium, Biotechnosphere, Saint Petersburg, Vol. 23-24, No.5-6, pp. 13-20.

70. Ignatov, I., Mosin, O. V. (2013) Isotopic Composition of Water and its Temperature in Modeling of Primordial Hydrosphere Experiments for Origin of Life and Living Matter, Science Review, Moscow, No.1, pp. 17-27.

71. Ignatov, I., Mosin, O. V. (2013) Isotopic Composition of Water and its Temperature in Modeling of Primordial Hydrosphere Experiments for Origin of Life and Living Matter, Acknowledge, Moscow, Vol. 14, No.1, pp. 1-16.

72. Ignatov, I., Mosin, O. V. (2013) Isotopic Composition of Water and Longevity, Acknowledge, Moscow, Vol. 14, No.1, pp. 2-10.

73. Ignatov, I., Mosin, O. V. (2013) Origin of Life and Living Matter in Hot Mineral Water, Acknowledge, Moscow, Vol. 15, No.2, pp. 1-19.

74. Ignatov, I., Mosin, O. V . (2013) Structure of Water for Origin of Life and Living Matter, Acknowledge, Moscow, Vol. 15, No.2, pp. 1-16.

75. Ignatov, I., Mosin, O. V .(2013) Isotopic Composition of Water and Origin of Life, School Biology, Moscow, No.3, pp. 5-16.

76. Mosin, O. V, Ignatov, I. (2013) Syntesis Natural Photo-Transforming Material Bacteriorhodopsin Derived from Halobacterium Halobium, HiTech, Radioelectronics, Moscow, No. 1, pp. 51-59.

77. Mosin, O. V, Ignatov, I. (2013) Microbiological Synthesis of Hihgly Deuterated Amino Acids - PHE, LEU/ILE, VAL and ALA whit using Methylotrophic Bacteria, 5th Int, Conference on Drug Discovery and Therapy, Pharmaceutical Biotechnology, Dubai.

78. Mosin, O. V, Ignatov, I. (2013) The Photo-Transforming Photochrome Protein Bacteriorhodopsin Derived from Photoorganoheterotrophic Halobacterium Halobium, Nanoengineering, Moscow, No.1, pp. 14-21.

79. Mosin, O. V, Ignatov, I. (2013) Methylotrophic Bacteria: Evolution and Metabolism, School Biology, Moscow, No. 1, pp. 3-13.

80. Ignatov, I., Mosin, O. V. (2013) Method for Color Coronal (Kirlian) Spectral Analysis, Biomedical Radio electronics, Biomedical Technologies and Radio electronics, Moscow, No.1, pp. 38-47.

81. Ignatov, I., Mosin, O. V. (2013) Isotopic Composition of Water and Longevity, Consciousness and Physical Reality, Natural Science, Vol. 18, No.1, pp. 26-32.

82. Ignatov, I., Mosin, O.V. (2013) Isotopic Composition of Water and Longevity, Chemistry, Moscow, No.4

83. Ignatov, I., Mosin, O. V., Velikov, B. (2013) Mathematical Models, Describing Structure of Water, Acknowledge, Moscow, Vol. 16. No.3, pp. 1-25.

84. Ignatov, I., Mosin , O.V. (2013) Color Coronal (Kirlian) Spectral Analysis in Modeling of Nonequilibrioum Conditions with the Gas Electric Discharges Simulating Primary Atmosphere. S. Miller's Experiments, Acknowledge, Moscow, Vol. 16, No. 3, pp. 1-15.

85. Mosin, O. V., I. Ignatov, I. (2013) Microbiological Synthesis of ${ }^{2} \mathrm{H}-$ Labeled Phenylalanine, Alanine, Valine, and Leucine/Isoleucine with Different Degrees of Deuterium Enrichment by the Gram-Positive Facultative Methylotrophic Bacterium Brevibacterium Methylicum, International Journal of BioMedicine, Biotechnology, Vol. 3, No.2, pp. 132-138.

86. Mosin, O. V., Shvets, V. I, Skladnev, D. A., Ignatov, I. (2013) Microbiological Synthesis of $\left[{ }^{2} \mathrm{H}\right]-$ inosine with High Degree of Isotopic Enrichment by Gram-positive Chemoheterotrophic Bacterium Bacillus Subtilis, Applied Biochemistry and Microbiology, Vol. 49, No.3, pp. 255-266.

87. Mosin, O. V., Shvets, V. I, Skladnev, D. A., Ignatov, I. (2013) Biosynthesis of Tran membrane Photo Transforming Protein Bacteriorhodopsin Labeled with Deuterium on Residues of Aromatic Acids [2, 3, 4, 5, $\left.6-\mathrm{H}_{5}\right]$ Phe[3, $\left.5-{ }^{2} \mathrm{H}_{2}\right]$ Tyr and [2, 4, 5, 6, $\left.7-<\sup 2<\sup =" ">\mathrm{H}_{5}\right]$ Trp, Analytical Instrumentation, Vol. 23, No. 2, pp. 14-26. 
88. Mosin, O. V., I. Ignatov, I. (2013) Preparation of Nanoparticles of Colloid Silver and Spheres of Their Practical Using, Moscow, Nanoengeneering, No. 5, pp. 23-30.

89. Ignatov, I., Mosin, O. V. (2013) Isotopic Composition of Water and Longevity, Astrahan Newspaper of Ecological Development, Astrahan, No. 2, pp. 127-136.

90. Ignatov, I., Mosin, O. V. (2013) Isotopic Composition of Water and its Temperature in the Process of Evolutional Development of Life and Living Matter, Astrahan Newspaper of Ecological Development, Astrahan, No. 1, pp. 113-127.

91. Mosin, O. V., I. Ignatov, I. (2013) The Composition and Properties of Fullerene Natural Mineral Shungite, Nano and Microsystem Technique, Moscow, No. 1, pp. 21-26.

92. Ignatov, I., Mosin, O. V. (2013) Composition of Water and Longevity, Newspaper of Development of Science and Education, Moscow, No. 2, pp. 3-13.

93. Ignatov I., Mosin O.V. (2013) Process of Perception of Light and Evolution of Sight at the Higher Animals and Humans, Acknowledge, Moscow, Vol. 3, No. 16, pp. 1-19.

94. Ignatov I., Mosin O.V. (2013) Possible Processes for Origin of Life and Living Matter in Deuterium Enriched Hot Mineral Water, Acknowledge, Moscow, Vol. 3, No. 16, pp. 1-12.

95. Ignatov, I., Mosin, O. V. (2013) Mathematical Models Describing Water Nanostructure and Nanoclusters, Newspaper of Development of Science and Education, Moscow, No. 3. pp. 3-22.

96. Ignatov I., Mosin O.V. (2013) Possible Processes for Origin of Life and Living Matter with modeling of Physiological Processes of Bacterium Bacillus Subtilis in Heavy Water as Model System, Journal of Natural Sciences Research, Vol. 3, No. 9, pp. 65-76.

97. Ignatov, I., Mosin, O. V. (2013) Structural Mathematical Models Describing Water Clusters, Journal of Mathematical Theory and Modeling, Vol. 3, No. 11, pp. 72-87.

98. Ignatov, I. Mosin, O. V. (2013) Biological Effect of Deuterium on Prokaryotic and Eukaryotic Cells, Astrahan Newspaper of Ecological Development, Astrahan, No. 3, pp. 124-138.

99. Ignatov, I., Mosin, O. V. (2013) Ecology, Nature, Longevity, V Int. Congress "Health of Planet", PsyAcademy, Czech Republic, pp. 54-56.

100. Mosin, O. V., Ignatov, I. (2013) The Structure and Composition of Natural Carbonaceous Fullerene Containing Mineral Shungite, International Journal of Advanced Scientific and Technical Research, Issue 3, Vol. 6, No. 11-12, pp. 9-21

101. Ignatov, I., Mosin, O. V. (2013) Modeling of Possible Processes for Origin of Life and Living Matter in Hot Mineral and Seawater with Deuterium, Journal of Environment and Earth Science, Vol. 3, No. 14, pp. 103-118.

102. Ignatov, I. Mosin, O. V. (2013) Studying of the Biosynthesis of ${ }^{2} \mathrm{H}$ - Labeled Inosine by a Grampositive Chemoheterotrophic Bacterium Bacillus Subtilis B-3157 on Heavy Water $\left(2 \mathrm{H}^{2} \mathrm{O}\right)$ Medium, Journal of Chemical and Engineering Research, Vol. 15, pp. 32-45.

103. Ignatov, I., Mosin, O.V. (2013) Mathematical Models Describing Water Nano Clusters, Consciousness and Physical Reality, Natural Science, Moscow, Vol. 18, No. 9, pp. 20-32.

104. Mosin, O.V., Ignatov, I. (2013) Evolution and Metabolism of Halophilic Microorganisms, Consciousness and Physical Reality, Natural Science, Moscow, Vol. 18, No. 7, pp. 6-16.

105. Mosin, O.V., Ignatov, I. (2013) Colloid Silver in Nano - biotechnologies (Overview), Consciousness and Physical Reality, Natural Science, Moscow, Vol. 18, No. 5, pp. 30-37.

106. Ignatov, I., Mosin, O.V. (2013) Isotopic Composition of Water and its Temperature in Modeling of Primordial Hydrosphere Experiments for Origin of Life and Living Matter, Consciousness and Physical Reality, Natural Science, Moscow, Vol. 18, No. 4, pp. 26-32.

107. Mosin, O. V., Ignatov, I., Skladnev, D. A., Shvets, V. I. (2013) A Strain of Gram-positive Chemoterothrophic Bacterium Bacilllus Subtilis - Producer of $\left[{ }^{2} \mathrm{H}\right]$ Riboxine, Drug Development and Registration, Moscow, Vol. 5, No. 5, pp.110-119.

108. Mosin, O.V., Ignatov, I. (2013) Extraction of Heavy Isotopes of Deuterium, Tritium and Oxigen, Water and Water Purification Technologies, Kiev, Vol. 12, No.2

109. Ignatov, I., Mosin, O.V. (2013) Perspective for the Use of Shungite in Water Treatment, Communal Complex of Russia, Vol. 113, No. 11, pp.1-5.

110. Ignatov, I., Mosin, O.V. (2014) Biomembrane Technologies in Water Treatment, Communal Complex of Russia, Vol. 116, No. 2, pp. 1-4.

111. Ignatov, I., Mosin, O.V. (2014) Photoreceptors in Visual Perception and Additive Color Mixing. Bacteriorhodopsin in Nano-and Biotechnologies, Advances in Physics Theories and Applications, Vol. 27, pp. $20-37$.

112. Mosin, O. V., Ignatov, I. (2013) Composition and Structural properties of Fulleren Analogious Shungite, Biotechnosphere, No. 1, pp. 29-33.

113. Mosin, O. V., Ignatov, I. (2013) Studying of Adaptation to Deuterium Procariotic and Eucariotic Cells, 
No. 3, Astrahan Newspaper of Ecological Development, Astrahan, pp. 124-138.

114. Mosin, O. V., Ignatov, I., Skladnev, D. A, Shvets, V. I. (2014) Use of Gram-positive Chemoheterotrophic Bacterium Basillus Subtilis B-3157 with HNP-cycle of Carbon Assimilation for Microbiological Synthesis of $\left[{ }^{2} \mathrm{H}\right]$ riboxine with High Level of Deuterium Enrichment, European Journal of Molecular Biotechnology, No.2, pp. 63-78.

115. Ignatov, I., Mosin, O. V. (2014) The Structure and Composition of Carbonaceous Fullerene Containing Mineral Shungite and Microporous Crystalline Aluminosilicate Mineral Zeolite. Mathematical Model of Interaction of Shungite and Zeolite with Water Molecules, Advances in Physics Theories and Applications, Vol. 28, pp. 10-21.

116. Mosin, O. V., Shvets, V. I, Skladnev, D. A, Ignatov, I. (2013) Microbial Synthesis of ${ }^{2}$ H-labelled Lphenylalanine with Different Levels in Isotopic Enrichment by a Facultative Methylotrophic Brevibacterium Methylicum with RuMP Assimilation of Carbon, Supplement Series B: Biomedical Chemistry, Vol. 7, No.3, pp. 247-258.

117. Mosin, O. V., Ignatov, I. (2014) Biosynthesis of Photochrome Transmembrane Protein Bacteriorhodopsin of Halobacterium Halobium Labeled with Deuterium at aromatic Amino Acids Residues of 2, 3, 4, 5, 6- $\left.{ }^{2} \mathrm{H}_{5}\right]$ Phe $\left[3,5-{ }^{2} \mathrm{H}_{2}\right]$ Tyr and $\left[2,4,5,6,7-{ }^{2} \mathrm{H}_{5}\right]$ Trp., Chemistry and Materials Research, Vol. 6, No.3, pp. 38-49.

118. Ignatov, I., Mosin, O. V. (2014) Composition and Structural properties of Fulleren Analogious Shungite, Mathematical Model of Interaction of Shungite with Water Molecules, Acknowledge, Moscow, Vol. 2, No.21, pp. 1-17.

119. Ignatov, I., Mosin, O. V., Velikov, B., Bauer, E. Tyminski, G. (2014) Longevity Factors and Mountain Water as Factor. Research in Mountain and Fields Areas in Bulgaria, Civil and Environmental Research, Vol. 30, No. 4, pp. 51-60.

120. Ignatov, I., Mosin, O. V., Niggli, H., Drossinakis, Ch. (2014) Evaluating of Possible Methods and Approaches for Registering of Electromagnetic Waves Emitted from the Human Body, Advances in Physics Theories and Applications, Vol. 30, pp. 15-33.

121. Ignatov, I., Mosin, O.V., Drossinakis, Ch. (2014) Infrared Thermal Field Emitted from Human Body. Thermovision, Journal of Medicine, Physiology, Biophysics, Vol. 1, pp. 1-12.

122. Ignatov, I., Mosin, O.V., Velikov, B. (2014) Longevity Factors and Mountain Water of Bulgaria in Factorial Research of Longevity, Journal of Medicine, Physiology, Biophysics,Vol. 1, pp. 13-33.

123. Mosin,O.V., Ignatov, I. (2014) Biological Influence of Deuterium on Prokaryotic and Eukaryotic Cells, Journal of Medicine, Physiology, Biophysics, Vol. 1, pp. 52-72.

124. Ignatov, I., Mosin,O.V. (2014) Preparation of Highly deuterated Phenylalanine, Alanine, Valine and Leucine/Isoleucine Using Facultative Methylotrophic Bacterium Brevibacterium Methylicum, Journal of Medicine, Physiology, Biophysics, Vol. 1, pp. 34-51.

125. Ignatov, I., Mosin,O.V. (2014) Studying Biosynthetic Pathways of ${ }^{2} \mathrm{H}-$ Labeled Purine Ribonucleoside Inosine in Bacterium Bacillus Subtilis B-3157 by FAB Method, Journal of Medicine, Physiology, Biophysics, Vol. 1, pp. 73-90.

126. Ignatov, I., Mosin,O.V. (2014) Visual Perception. Electromagnetic Conception for the Eyesight. Rhodopsin and Bacteriodopsin, Journal of Medicine, Physiology and Biophysics, Vol. 2, pp. 1-19.

127. Ignatov, I., Mosin,O.V. (2014) The Structure and Composition of Shungite and Zeolite. Mathematical Model of Distribution of Hydrogen Bonds of Water Molecules in Solution of Shungite and Zeolite, Journal of Medicine, Physiology and Biophysics, Vol. 2, pp. 20-36.

128. Ignatov, I., Mosin,O.V., Velikov, B., Bauer, E., Tyminski, G. (2014) Research of Longevity Factors and Mountain Water as a Factor in Teteven Municipality, Bulgaria, Journal of Medicine, Physiology and Biophysics, Vol. 2, pp. 37-52.

129. Ignatov, I., Mosin,O.V. (2014) Modeling of Possible Processes for Origin of Life and Living Matter in Hot Mineral Water. Research of Physiological Processes of Bacterium Bacillus Subtilis in Hot Heavy Water, Journal of Medicine, Physiology and Biophysics, Vol. 2, pp. 53-70.

130. Ignatov, I., Mosin,O.V. (2014) Mathematical Models of Distribution of Water Molecules Regarding Energies of Hydrogen Bonds, Journal of Medicine, Physiology and Biophysics, Vol. 2, pp. 71-94.

131. Mosin, O. V., Ignatov, I., Skladnev, D. A., Shvets, V. I., (2014) Using of Facultative Methylotrophic Bacterium Brevibacterium Methylicum B-5652 with RMP-cycle of Carbon Assimilation for Microbiological Synthesis of $\left[{ }^{2} \mathrm{H}\right]$ Phenylalanine with Different Levels of Different Levels of Deuterium Enrichment, European Journal of Molecular Biotechnology, Vol. 3, No.1, pp. 25-40.

132. Mosin,O.V., Ignatov, I. (2014) The Natural Phototransforming Photochrome Membrane Protein Bacteriorhodopsin from Halobacterium Halobacterium Halobium, European Journal of Molecular Biotechnology, Vol. 1, No.1, pp. 25-40.

133. Ignatov, I., Mosin,O.V. (2014) Modeling of Possible Conditions For Origin of First Organic Forms in 
Hot Mineral Water, Journal of Medicine, Physiology and Biophysics, Vol. 3., pp. 1-14.

134. Ignatov, I., Mosin,O.V. (2014) Mathematical Model of Interaction of Carbonaceous Fullerene Containing Mineral Shungite and Aluminosilicate Mineral Zeolite with Water, Journal of Medicine, Physiology and Biophysics, Vol. 3., pp. 15-29.

135. Ignatov, I., Mosin,O.V. (2014) Studying of Phototransformans of Light Signal by Photoreceptor Pigments - Rhodopsin, Iodopsin and Bacteriorhopsin and Additive Mixing of Colors, Journal of Medicine, Physiology and Biophysics, Vol. 3., pp. 30-47.

136. Mosin,O.V., Ignatov, I. (2014) Shungite, Structure and Properties of the Mineral, Nanoindustry, Vol. 3, No.41, pp. 32-38.

137. Ignatov, I., Mosin,O.V. (2014) Mathematical Models Describing Water Clusters as Interaction among Water Molecules. Distributions of Energies of Hydrogen Bonds, Journal of Medicine, Physiology and Biophysics, Vol. 3., pp. 48-70.

138. Mosin,O.V., Ignatov, I. (2014) Improved of Method for Isolation of Photochrome Transmembrane Protein Bacteriorhodopsin from Purple Membranes of Halobacterium Halobacterium Halobium, Journal of Medicine, Physiology and Biophysics, Vol. 3., pp. 71-86.

139. Atanasov, A., Karadzhov, S., Ivanova, E., Mosin, O. V., Ignatov, I. (2014) Study of the Effects of Electrochemical Aqueous Sodium Chloride Solution (Anolite) on the Virus of Classical Swine Fever Virus. Mathematical Models of Anolyte and Catolyte as Types of Water, Journal of Medicine, Physiology and Biophysics, Vol. 4, pp. 1-26.

140. Ignatov, I., Mosin, O. V., Bauer, E. (2014) Carbonaceous Fullerene Mineral Shungite and Aluminosilicate Mineral Zeolite. Mathematical Model ans Practical Application of Water Solution of Water Shungite and Zeolite, Journal of Medicine, Physiology and Biophysics, Vol. 4, pp. 27-44.

141. Ignatov, I., Mosin, O. V. (2014) Research of Isotopic Effects of Deuterium in Cells of Microorganisms in the Presence of $\mathrm{D}_{2} \mathrm{O}$ in IR Spectra in Hot Mineral Water for Origin of Life, Journal of Medicine, Physiology and Biophysics, Vol. 4, pp. 45-57.

142. Ignatov, I., Mosin, O. V. (2014) Nature of Hydrogen Bonds in Liquids and Crystals. Ice Crystal Modifications and Their Physical Characteristics, Journal of Medicine, Physiology and Biophysics, Vol. 4, pp. 58-80.

143. Mosin,O.V., Ignatov, I. (2014) Photochrome Transmembrane Protein Bacteriorhodopsin from Purple Membranes of Halobacterium Halobium in Nano- and Biotechnologies, Journal of Medicine, Physiology and Biophysics, Vol. 4, pp. 81-99.

144. Ignatov, I., Mosin, O. V. (2014) Visual Perception and Electromagnetic Conception for the Eyesight. Rhodopsin and Bacteriorhodopsin in Nano- and Biotechnologies, Journal of Health, Medicine and Nursing, Vol. 4., pp. 1-20.

145. Ignatov, I., Mosin, O.V., Velikov, B., Bauer, E., Tyminski, G. (2014) Research of Longevity Factors and Mountain Water as a Factor in Teteven, Yablanitsa and Ugarchin Municipalities, Lovech Region, Bulgaria, Journal of Health, Medicine and Nursing, Vol. 4., pp. 21-36.

146. Mosin, O.V., Ignatov, I. (2014) Facultative Methylotrophic Bacterium Brevibacterium Methylicum in the Process of Preparation of Highly Deuterated Phenylalanine, Alanine, Valine and Leucine/Isoleucine, Journal of Health, Medicine and Nursing, Vol. 4., pp. 37-56.

147. Mosin, O.V., Ignatov, I. (2014) Isolation of Photochrome Transmembrane Protein Bacteriorhodopsin from Purple Membranes of Halobacterium Halobacterium Halobium, New Methods for Isolation, Vol. 4., pp. 57-73.

148. Mosin, O.V., Ignatov, I. (2014) Research from a Bacterium Bacillus Subtilis B-3157 by FAB Method of Biosynthetic Pathways of $2 \mathrm{H}$-Labeled Purine Ribonucleoside Inosine, Journal of Health, Medicine and Nursing, of Health, Medicine and Nursing, Vol. 4., pp. 74-93.

149. Mosin, O.V., Ignatov, I. (2014) Basic Concept of Magnetic Water Treatment, European Journal of Molecular Biotechnology, Vol. 4, No.2, pp. 72-85.

150. Ignatov, I. Mosin, O.V., Velikov, B. Bauer, E., Tyminski, G. (2014) Mountain Water as Main Longevity Factor in Research of Phenomenon of Longevity in Mountain Areas in Bulgaria, European Journal of Molecular Biotechnology, Vol. 4, No.2, pp. 52-71.

151. Ignatov, I., Mosin, O. V., Niggli, H., Drossinakis, Ch., Stoyanov, Ch. (2014) Registration of Electromagnetic Waves Emitted the Human Body, Journal of Medicine, Physiology and Biophysics, Vol. 5, pp. 1-22.

152. Ignatov, I., Mosin, O. V. (2014) Modeling of Possible Processes for Origin of Life and Living Matter in Sea and Hot Mineral Water. Process of Formation of Stromatolites, Journal of Medicine, Physiology and Biophysics, Vol. 5, pp. 23-46.

153. Ignatov, I., Mosin, O. V. (2014) Coronal Gas Discharge Effect in Modeling of Non-Equilibrium Conditions with Gas Electric Discharge Simulating Primary Atmosphere and Hydrosphere for Origin of Life 
and Living Matter, Journal of Medicine, Physiology and Biophysics, Vol. 5, pp. 47-70.

154. Mosin, O. V., Ignatov, I. (2014) Phenomenon of Biological Adaptation to Deuterium Oxide, Journal of Medicine, Physiology and Biophysics, Vol. 5, pp. 71-107.

155. Mosin, O. V., Ignatov, I. (2014) The Strain of Facultative Methylotrophic Bacterium Brevibacterium Methylicum 5662 with RuMP Cycle of Carbon Assimilation for Biosynthesis of Deuterium Labeled Phenylalanine, Journal of Medicine, Physiology and Biophysics, Vol. 5, pp. 108-128.

156. Ignatov, I., Mosin, O. V., Bauer, E. (2014) Mathematical Model and Practical Application of Water Solution of Shungite and Zeolite. Composition of Aluminosilicate Mineral Zeolite and Carbonaceous Fullerene Containing Mineral Shungite, Journal of Health, Medicine and Nursing, Vol. 5, pp. 12-29.

157. Karadzov, S., Atanasov, A., Ivanova, E., Mosin, O. V., Ignatov, I. (2014) Mathematical Models of Electrochemical Aqueous Sodium Chloride Solutions (Anolyte and Catolyte) as Types of Water. Study of the Effects of Anolyte on the Virus of Classical Swine Fever Virus, Journal of Health, Medicine and Nursing, Vol. 5, pp. 30-55.

158. Ignatov, I., Mosin, O. V. (2014) Hydrogen Bonds among Molecules in Liquid and Solid State of Water. Modifications of Ice Crystals, Journal of Health, Medicine and Nursing, Vol. 5, pp. 56-79.

159. Ignatov, I., Mosin, O. V. (2014) Microorganisms in the Presence of $\mathrm{D}_{2} \mathrm{O}$ and IR Spectra in Hot Mineral Water with More Deuterium Atoms for Origin of Life and Living Matter, Journal of Health, Medicine and Nursing, Vol. 5, pp. 80-93.

160. Mosin, O. V., Ignatov, I. (2014) Photochrome Transmembrane Protein Bacteriorhodopsin from Purple Membrane of Halobacterium Halobium. Applications in Bio- and Nanotechnologies, Journal of Health, Medicine and Nursing, Vol. 5, pp. 94-112.

161. Ignatov, I., Mosin, O.V., Stoyanov, Ch. (2014) Biophysical Fields. Color Coronal Spectral Analysis. Registration with Water Spectral Analysis. Biophoton Emission, Journal of Medicine, Physiology and Biophysics, Vol. 6, pp. 1-22.

162. Mosin, O.V., Ignatov, I. (2014) Biosynthesis of Deuterium-labeled Transmembrane Protein Bacteriorhodopsin using a Halobacterium Halobium, Journal of Medicine, Physiology and Biophysics, Vol. 6, pp. 23-41.

163. Mosin, O.V., Ignatov, I. (2014) Photochrome Protein Bacteriorhodopsin Protein from Purple Membranes of Halobacterium Halobium. Application Applications in Bio- and Nanotechnologies, Journal of Medicine, Physiology and Biophysics, Vol. 6, pp. 42-60.

164. Mosin, O.V., Ignatov, I. (2014) Metabolism and Physiology of Methylotrophic Microorganisms, Journal of Medicine, Physiology and Biophysics, Vol. 6, pp. 61-84.

165. Mosin, O.V. \& Ignatov, I. (2014) On the Nature of Biological Adaptation on Deuterium Oxide, Journal of Medicine, Physiology and Biophysics, Vol. 6, pp. 85-121.

166. Ignatov, I., Mosin, O.V. (2014) Hot Mineral Water with More Deuterium for Origin of Live and Living Matter. Process of Formation of Stromatolites, Journal of Health, Medicine and Nursing, Vol. 6, pp. 1-24.

167. Ignatov, I., Mosin, O.V. (2014) Origin of Life and Living Matter in Primary Atmosphere and Hydrosphere. Modeling of Non-equilibrium Electric Gas Discharge Conditions, Journal of Health, Medicine and Nursing, Vol. 6, pp. 25-49.

168. Ignatov, I., Mosin, O.V. (2014) Methods for Measurements of Water Spectrum. Differential Nonequilibrium Energy Spectrum Method (DNES), Journal of Health, Medicine and Nursing Vol. 6, pp. 50-72.

169. Mosin, O.V., Ignatov, I. (2014) Phenomenon of Biological Adaptation to Heavy Water, Journal of Health, Medicine and Nursing, Vol. 6, pp. 73-110. Mosin, O.V., Ignatov, I. (2014) Biosynthesis of Deuterium Labeled Phenylalanine. Facultative Methylotrophic Bacterium Brevibacterium Methylicum \#5662 with RuMP Cycle of Carbon Assimilation, Journal of Health, Medicine and Nursing, Vol. 6, pp. 111132 .

170. Ignatov, I., Mosin, O. V., Water Structural Models Describing Cyclical Nano-clusters, Nano and Microsystem Technique, Moscow, No.3, pp. 47-56.

171. Ignatov, I., Mosin, O. V. (2014) Color Coronal Spectral Analysis in Modeling of Non-Equilibrium Conditions with Gas Electric Discharge Simulating Primary Atmosphere, Biomedical Radioelectronic, Moscow, No.2, pp. 42-51.

172. Mosin, O. V, Ignatov, I. (2014) Biosynthesis of $\left[{ }^{2} \mathrm{H}\right]$ phenylalanine with Different Levels of Isotopic Enrichment, Produced by Facultative Methylotrophic Bacterium Brevibacterium Methylicum with RMPcycle Assimilation of Carbon, Questions of Biological, Medical and Pharmaceutical Chemistry, Moscow, No.2, pp. 53-66.

173. Ignatov, I., Mosin, O. V. (2013) Structural Models of Water, Describing Cyclic Nanoclusters, Nanomaterials and Nanostructures - XXI Century, Moscow, No. 4, pp. 9-20.

174. Mosin, O. V, Ignatov, I. (2014) Methods for Preparing of Colloid Silver, Nano and Microsystem Technique, Moscow, No.2, pp. 46-52. 
175. Mosin, O. V, Ignatov, I. (2014) The Phototransforming Photochrome Transmembrane Protein Bacteriorhodopsin from Purple Membranes of Halobacterium Halobacterium Halobium, Nanomaterials and Nanostructures - XXI Century, Moscow, No.1, pp. 9-17.

176. Ignatov, I., Mosin, O. V. (2014) Color Coronal (Kirlian) Spectral Analysis in Modeling of NonEquilibrium Conditions with Gas Electric Discharge Simulating Primary Atmosphere, Nano and Microsystem Technique, Moscow, No. 8, pp. 8-15.

177. Ignatov, I., Mosin, O. V. (2014) Modeling of the Conditions in Primary Hydrosphere in the Process for the Origination of Organic Forms of Life in Hot Mineral Water, No. 6, pp. 37-48.

178. Mosin, O. V, Ignatov, I. (2012) Perspectives of Executing of Fulleren Analogious Shungite in Water Preparation, Energy Saving and Water Preparation, Moscow, No. 5, pp. 13-18.

179. Mosin, O. V, Ignatov, I. (2014) Biological Influence of Deuterium on Procariotic and Eukariotic Cells, European Journal of Molecular Biotechnology, Vol. 3, No. 1, pp. 11-24

180. Ignatov, I., Mosin, O. V. (2014) The Structure and Composition of Carbonaceous Fullerene Containing Mineral Shungite and Microporous Crystalline Aluminosilicate Mineral Zeolite, Nanotechnology Research and Practice, Vol. 1, No. 1, pp. 30-42.

181. Mosin, O. V, Ignatov, I. (2014) Biological Influence on the Prokaryotic and Eukaryotic Cells, Technologies of Living Systems, Moscow, No. 1, pp. 21-33.

182. Mosin, O. V, Ignatov, I. (2014) Studying of Phototransformation of Light Signal by Photoreceptor Pigments - Rhodopsin, Iodopsin and Bacteriorhodopsin, Nanotechnology Research and Practice, Vol. 2, No. 2, pp. 80-95.

183. Ignatov, I., Mosin, O. V., Niggli, H., Drossinakis, Ch. (2014) Evaluating of Possible Methods and Approaches for Registering Electromagnetic Waves Emitted from the Human Body, Nanotechnology Research and Practice, Vol. 2, No. 2, pp. 96-116.

184. Ignatov, I., Mosin O.V. (2012) Isotopic composition of water and its temperature in modeling primordial hydrosphere experiments, VII Int. Conference Future Studies in Science and Technology, Veterinary Biological Science, Prague, Vol. 15, pp. 41-49.

185. Ignatov, I., Mosin, O. V. (2013) Mathematical Models Describing Water Clusters and Nanoclusters, Newspaper of Development of Science and Education, Moscow, No. 3, pp. 3-30.

186. Ignatov, I., Mosin, O. V. (2013) Methods for Preparation of Nano Particles of Colloid Silver and Practical Applications, Newspaper of Development of Science and Education, Moscow, No. 3, pp. 30-42.

187. Mosin, O.V., Ignatov, I. (2014) Preparative Microbiological Synthesis of Highly Deuterated $\left[{ }^{2} \mathrm{H}\right]$ inosine by Gram-positive Chemoheterotrophic Bacterium Bacillus subtilis B-3157 on Heavy water $\left({ }^{2} \mathrm{H}_{2} \mathrm{O}\right)$ Medium, 6th Int. Conference on Drug Discovery and Therapy, Pharmaceutical Biotechnology, Dubai. U.A.E. P.p. 124.

188. Mosin, O. V., Ignatov, I. (2014) Magnetic Water Treatment, Communal Complex, Moscow, No.12, pp. 46-50.

189. Ignatov, I., Mosin, O. V. (2013) Isotopic Composition of Water and Longevity, Water: Hygiene and Ecology, No.3-4, pp. 22-32.

190. Mosin, O.V., Ignatov, I., Skladnev, D.A., Shvets, V.I.(2014) Microbiological Synthesis of ${ }^{2}$ H- and $13 C-$ Labeled Amino Acids and Proteins With Various Levels of Isotopic Enrichment, European Reviews of Chemical Research, Vol. 2, No. 2. pp. 109-132.

191. Mosin O.V., Ignatov I., Skladnev D.A., Shvets V.I. (2014) Biosynthetic incorporation of deuteriumlabeled aromatic amino acids - [2,3,4,5,6 - $\left.{ }^{2} \mathrm{H}_{5}\right]$ phenylalanine, $\left[3,5-{ }^{2} \mathrm{H}_{2}\right]$ tyrosine and $\left[2,4,5,6,7-{ }^{2} \mathrm{H}_{5}\right]$ tryptophan into the molecule of transmembrane protein bacteriorhodopsin from Halobacterium Halobacterium Halobium, European Reviews of Chemical Research, Vol. 2, No. 2, pp. 92-108.

192. Ignatov I., Mosin O.V. (2014) Coronal Effect in Modeling of Non-Equilibrium Conditions with the Gas Electric Discharge, Simulating Primary Atmosphere, Nanotechnology Research and Practice, Vol. 3, No. 3, pp. 127-140

193. Mosin O.V., Ignatov I. (2014) Methods for Preparation of Microdispersed Colloid Silver Nanoparticles, Nanotechnology Research and Practice, Vol. 4. No.4, pp. 201-212.

194. Mosin, O. V, Ignatov, I. (2013) The Phototransforming Photochrome Transmembrane Protein Bacteriorhodopsin from Purple Membranes of Halobacterium Halobacterium Halobium, Nano- and Microsystem Technique, Moscow, No. 3, pp. 127-140.

195. Ignatov I., Mosin O.V. (2014) Coronal Effect for Modeling of Non-Equilibrium Conditions with the Gas Electric Discharge, Simulating Primary Atmosphere, Nano- and Microsystem Technique, Moscow, No. 8, pp. 8-15.

196. Mosin, O. V, Ignatov, I. (2013) Methods for Preparation of Nano Particles of Colloid Silver and Practical Applications, Nanoengineering, No. 6, pp. 23-29.

197. Mosin, O. V, Ignatov, I. (2013) The Natural Phototransforming Photochrome Membrane Protein 
Bacteriorhodopsin from Halobacterium Halobacterium Halobium, Nanoengineering, Moscow, No. 6, pp. 36-42.

198. Ignatov I., Mosin O.V. (2013) Mathematical Models Describing Water Clusters, Nanoengineering, Moscow, No. 8, pp. 23-34.

199. Ignatov I., Mosin O.V. (2013) Color Coronal Spectral Analysis for Modeling of Non-Equilibrium Conditions with the Gas Electric Discharge, Simulating Primary Atmosphere, Nanoengineering, Moscow, No. 12, pp. 41-51.

200. Mosin, O.V., Shvets, V.I., Skladnev, D.A., Ignatov, I. (2014)Microbiological synthesis of $\left[{ }^{2} H\right]$ Labeled L- phenylalanine Produced Facultative Methylotrophic Bacterium Brevibacterium Methylicum with RuMP Cycle of Carbon Assimilation, Biomedical Chemistry, Moscow, Vol. 60, No. 4, pp. 448-461.

201. Ignatov, I., Mosin, O. V. (2013) Ideas about the Origin of Life in the Light of the Study of the Properties of the Natural Water, Chemistry, Moscow, No. 10, pp. 3-9.

202. Mosin, O. V., Shvets, V. I., Skladnev, D. A., Ignatov, I. (2013) Biosynthesis of $\left[{ }^{2} H\right]$ Phenylalanine Produced Facultative Methylotrophic Bacterium Brevibacterium methylicum, Chemical Technology, Moscow, No. 3, pp. 171-184.

203. Ignatov I., Mosin O.V. (2014) Study of Gas Discharge Glow of Biological Objects and Water with Method of Color Coronal Spectral Analysis, Nanoengineering, Moscow, No. 10, pp. 12-21.

204. Ignatov I., Mosin O.V. (2014) Modeling of Conditions in Primary Hydrosphere in the Process of Origination of Organic Forms of Life in Hot Mineral Water, Nanoengineering, Moscow, No. 6, pp. 37-46.

205. Mosin, O. V, Ignatov, I. (2013) Composition and Structural Properties of Fulleren Analogious Shungite, Biotechnosphere, Saint-Petersburg, Vol. 25, No. 1, pp. 29-33.

206. Ignatov, I., Mosin, O. V., Velikov, B., Bauer, E. (2014) Mountain Water as Main Factor of Longevity in Study of the Phenomenon Longevity in Bulgarian Mountains, Questions of Biological, Questions of Medical and Pharmaceutical Chemistry, Moscow, No. 10, pp. 27-41.

207. Ignatov, I., Mosin, O.V. (2014) Biological Influence of Deuterium on the Cells Prokaryotes and Eukaryotes, Technologies of Living Systems, Moscow, No. 2, pp. 21-33.

208. Mosin, O. V, Ignatov, I. (2012) The Natural Phototransforming Photochrome Membrane Protein Bacteriorhodopsin from Halobacterium Halobium, Nanomaterials and Nanotechnologies, Moscow, No. 2, pp. 47-57.

209. Ignatov, I., Mosin, O.V. (2012) Mathematical Models Water, XIII Int. Conference "Modern Problems of Humanitarian and Natural Sciences, Vol. 1, pp. 47-52.

210. Mosin, O. V., Shvets, V. I., Skladnev, D. A., Ignatov, I. (2012) Synthesis of $\left[{ }^{2} \mathrm{H}\right]$ Bacteriorhodopsin Labeled with Deuterium at Aromatic Amino Acid Residues, Chemical Technologies, Moscow, No. 9, pp. 34-42.

211. Mosin, O. V., Ignatov, I. (2013) Fulleren Analogious Mineral Shungite for Preparation of Buildings Materials, Buildings Materials, Equipment and Technologies XXI century, Moscow, Vol. 179, No.12, pp. 28-31.

212. Mosin, O. V., Ignatov, I. (2013) Design Features of Magnetic Hydrodynamic Cells for Magnetic Preparation Water for Cement Mixtures, Buildings Materials, Equipment and Technologies XXI century, Moscow, No. 6, pp. 17-21.

213. Ignatov, I., Mosin, O.V. (2013) Mathematical Models Describing Nanostructure os Water and Water Clusters, Newspaper for Development of Science and Education, Moscow, No. 2, pp. 3-30.

214. Ignatov, I., Mosin, O.V. (2013) Structural Water Models Describing Cyclical Nanoclusters, Nanomaterials and Nanostructures, No. 4, pp. 9-20.

215. Mosin O.V., Ignatov I., Skladnev D.A., Shvets V.I. (2013) Biosynthetic Incorporation of Deuteriumlabeled Aromatic Amino Acids - [2,3,4,5,6 - $\left.{ }^{2} \mathrm{H}_{5}\right]$ phenylalanine, [3,5 - $\left.{ }^{2} \mathrm{H}_{2}\right]$ tyrosine and [2,4,5,6,7- $\left.{ }^{2} \mathrm{H}_{5}\right]$ tryptophan into the molecule of transmembrane protein bacteriorhodopsin from Halobacterium Halobacterium Halobium, Questions of Medical and Pharmaceutical Chemistry, Moscow, No. 8, pp. 28-40.

216. Mosin, O. V., Ignatov, I. (2014) Biosyntheses of $\left[{ }^{2} \mathrm{H}\right]$ phenylalanine Different Levels from Facultative Methylotrophic Bacterium Brevibacterium Methylicum with RuMP Cycle of Carbon Assimilation, Questions of Medical and Pharmaceutical Chemistry, Moscow, No. 2, pp. 53-65.

217. Mosin, O. V., Ignatov, I. (2013) Perspectives of Using of Fulleren Analogious Shungite in Water Preparation, Energy Saving and Water Preparation, Moscow, Vol. 85, No. 5, pp. 13-18.

218. Mosin, O. V., Ignatov, I. (2014) Biological Influence on Prokaryotic and Eukaryotic Cells, Drug Development and Registration, Moscow, Vol.7, No. 2, pp. 122-131.

219. Ignatov, I., Mosin, O. V. (2014) Isotopic Composition of Water as Main Factor for Longevity, Drug Development and Registration, Moscow, Vol. 9, No. 4, pp. 146-155.

220. Mosin, O. V., Ignatov, I., Skladnev, D. A, Shvets, V. I. (2014) A Strain of Gram-positive Facultative Methylotrophic Bacterium Brevibacterium Methylicum Producer of $\left[{ }^{2} \mathrm{H}\right]$ Phenylalanine, Drug Development 
and Registration, Moscow, No. 4, pp. 58-68.

221. Mosin, O. V., Ignatov, I., Skladnev, D. A, Shvets, V. I. (2014) Method of Preparation of Deuteriumlabeled Transmembrane Protein $\left[{ }^{2} \mathrm{H}\right]$ Bacteriorhodopsin from Purple Membranes of Halobacterium Halobacterium Halobium, Drug Development and Registration, Moscow, No. 3, pp. 158-167.

222. Mosin, O. V., Ignatov, I. (2014) Biosynthesis of deuterium labeled purine ribonucleoside riboxine with high levels of isotopic enrichment by chemo heterotrophic bacterium Bacillus subtilis, Questions of Medical and Pharmaceutical Chemistry, Moscow, No. 6, pp. 34-45.

223. Mosin, O. V., Ignatov, I. (2014) Halobacterium Halobium in the Process of Biosynthesis of Deuteriumlabeled Transmembrane Protein Bacteriorhodopsin, Journal of Medicine, Physiology and Biophysics, Vol. 8, pp. 1-21.

224. Mosin, O. V., Ignatov, I. (2014) Chemoheterotrophic Bacterium Bacillus Subtilis B-3157, Microbiological Preparation of Deuterium Labeled Purine Ribonucleoside Inosine from Bacillus Subtilis B3157, Journal of Medicine, Physiology and Biophysics, Vol. 8, pp. 22-45.

225. Ignatov, I., Mosin, O. V., Velikov, B., Bauer, E. (2014) Human Longevity. Mountain Water as Factor of Longevity. Research in Bulgaria, Journal of Medicine, Physiology and Biophysics, Vol. 8, pp. 46-78.

226. Mosin, O. V., Ignatov, I. (2014) Biological Adaptation to Deuterium Oxide (Heavy Water), Journal of Medicine, Physiology and Biophysics, Vol. 8, pp. 79-118.

227. Mosin, O. V., Ignatov, I. (2014) Deuterium L-Phenylalanine and Microbiological Preparation for Application in Medical Diagnostics, Journal of Medicine, Physiology and Biophysics, Vol. 8, pp. 119-143

228. Ignatov, I., Karadzhov, S., Atanasov, A., Ivanova, E., Mosin, O. V. (2014) Electrochemical Aqueous Sodium Chloride Solution (Anolyte and Catholyte) as Types of Water. Mathematical Models. Study of Effects of Anolyte on the Virus of Classical Swine Fever Virus, Journal of Health, Medicine and Nursing, Vol. 8, pp.1-28.

229. Ignatov, I., Mosin, O. V. (2014) The Methods for Studying the Structure of Water Clusters $\left(\mathrm{H}_{2} \mathrm{O}\right)$, where $n=3-20$. Water Clusters as Nano-structures, Journal of Health, Medicine and Nursing, Vol. 8, pp. 2958 .

230. Mosin, O. V., Ignatov, I. (2014) Biosynthesis of Deuterium-labeled Transmembrane Protein Bacteriorhodopsin from Halobacterium Halobium, Journal of Health, Medicine and Nursing, Vol. 8, pp. 5980 .

231. Mosin, O. V., Ignatov, I. (2014) Metabolism and Physiology of Methylotrophic Microorganisms, Journal of Health, Medicine and Nursing, Vol. 8, pp. 81-106.

232. Mosin, O. V., Ignatov, I. (2014) The Heavy Water as Medium of Biological Adaptation of Organisms, Journal of Health, Medicine and Nursing, Vol. 8, pp. 107-146.

233. Ignatov, I., Mosin, O. V., Stoyanov, Ch. (2014) Fields in Electromagnetic Spectrum Emitted from Human Body. Application in Medicine, Journal of Health, Medicine and Nursing, Vol. 7, pp. 1-22.

234. Ignatov, I., Mosin, O. V. (2014) The Methods for Studying the Structure of Water Clusters $\left(\mathrm{H}_{2} \mathrm{O}\right)$, where $n=3-20$, Application in Medicine, Journal of Health, Medicine and Nursing, Vol. 7, pp. 23-52.

235. Mosin, O. V., Ignatov, I. (2014) Halobacterium Halobium. Biosynthesis of Deuterium-labeled Transmembrane Protein Bacteriorhodopsin from Halobacterium Halobium, Journal of Health, Medicine and Nursing, Vol. 7, pp. 53-74.

236. Mosin, O. V., Ignatov, I. (2014) Methylotrophic Microorganisms. Metabolism and Physiology, Journal of Health, Medicine and Nursing, Vol. 7, pp. 75-100.

237. Mosin, O. V., Ignatov, I. (2014) Biological Adaptation of Organisms in Heavy Water, Journal of Health, Medicine and Nursing, Vol. 7, pp. 101-140.

238. Mosin, O. V., Ignatov, I. (2014) Biosynthesis of Deuterium-labeled Transmembrane Protein Bacteriorhodopsin using a Halobacterium Halobiu, Journal of Medicine, Physiology and Biophysics, Vol. 7, pp. 1-21.

239. Mosin, O. V., Ignatov, I. (2014) Microbiological Preparation of Deuterium Labeled Purine Ribonucleoside Inosine Using a Strain of Chemoheterotrophic Bacterium Bacillus Subtilis B-3157, Journal of Medicine, Physiology and Biophysics, Vol. 7, pp. 22-45.

240. Ignatov, I., Mosin, O. V., Velikov, B., Bauer, E. (2014) Influence of Isotopic Composition of Water with Varying Deuterium Content in Composition with Mountain Water of Bulgaria on Human Longevity, Journal of Medicine, Physiology and Biophysics, Vol. 7, pp. 46-78.

241. Mosin, O. V., Ignatov, I. (2014) On the Nature of Biological Adaptation to Deuterium Oxide, Journal of Medicine, Physiology and Biophysics, Vol. 7., pp. 79-118.

242. Mosin, O. V., Ignatov, I. (2014) Microbiological Preparation of Labeled L-Phenylalanine for Medical Diagnostics, Journal of Medicine, Physiology and Biophysics, Vol. 7, pp. 119-143.

243. Ignatov, I., Mosin, O.V. (2015) Origin of Life and Living Matter in Hot Mineral Water, Advances in Physics Theories and Applications, Vol. 39. pp. 1-22. 
244. Ignatov, I., Mosin, O.V., Niggli, H., Drossinakis, Ch. (2015) Non-Ionizing Radiation (NIR) Waves Emitting from Human Body, Journal of Medicine, Physiology and Biophysics, Vol. 9, pp. 1-26.

245. Ignatov, I., Mosin, O.V. (2015) Non-equilibrium Gas Discharge Conditions for Origin of Life and Living Matter. Experiments of Miller. Modeling of the Conditions with Gas Coronal Discharge Simulating Primary Atmosphere, Journal of Medicine, Physiology and Biophysics, Vol. 9, pp. 27-50.

246. Ignatov, I., Mosin, O.V., Velikov, B. (2015) Mountain Water as a Factor of Human Longevity. Local Extremum at $8.95 \mu \mathrm{m}$ in Spectrum of Water as Indicator for Health and Longevity, Journal of Medicine, Physiology and Biophysics, Vol. 9, pp. 51-81.

247. Ignatov, I., Mosin, O.V. (2015) Water: Solid and Liquid Phases. Nano Structures in the Water in Solid and Liquid Phases, Journal of Medicine, Physiology and Biophysics, Vol. 9, pp. 82-109.

248. Mosin, O.V., Ignatov, I. (2015) Construction of Magnetohydrodynamic Cell for Magnetic Treatment of Water, Journal of Medicine, Physiology and Biophysics, Vol. 9, pp. 110-124.

249. Ignatov, I., Mosin, O.V. (2015) Carbonaceous Fullerene Containing Mineral Shungite. Alunonusilicate Mineral Zeolite. Interaction of Water Molecules with Shungite and Zeolite, Journal of Health, Medicine and Nursing, Vol. 9, pp. 1-14.

250. Ignatov, I., Mosin, O. V. (2015) Bacterium Bacillus Subtilis, Preparation from Bacillus Subtilis B-3157 of 2H-Labeled Purine Ribonucleoside, Journal of Health, Medicine and Nursing, Vol. 9, pp. 34-51.

251. Mosin, O.V., Ignatov, I. (2015) Photochrome Transmembrane Protein Bacteriorhodopsin in Nano- and Biotechnologies, Journal of Health, Medicine and Nursing, Vol. 9, pp. 52-71.

252. Mosin, O.V., Ignatov, I. (2015) Heavy Water as Medium for the Life of Organisms, Journal of Health, Medicine and Nursing, Vol. 9, pp. 72-110.

253. Gluhchev, G., Ignatov, I., Karadzhov, S., Miloshev, G., Ivanov, I., Mosin, O.V. (2015) Electrochemically Activated Water. Biophysical and Biological Effects of Anolyte and Catholyte as Types of Water, Journal of Medicine, Physiology and Biophysics, Vol. 10, pp. 1-17.

254. Ignatov, I., Mosin, O.V. (2015) Studying the Properties of Microdispersed Colloid Silver Nanoparticles, Journal of Medicine, Physiology and Biophysics, Vol. 10, pp. 18-28. Mosin, O.V., Ignatov, I. (2015) Preparation from Bacterium Bacillus Subtilis B-3157 of 2H-Labaled Purine Ribonucleoside Inosine, Journal of Medicine, Physiology and Biophysics, Vol. 10, pp. 29-46.

255. Mosin, O.V., Ignatov, I. (2015) The Isotopic Effect of Deuterium on Biological Objects, Journal of Medicine, Physiology and Biophysics, Vol. 10, pp. 47-70.

256. Mosin, O.V., Ignatov, I. (2015) Anatomy and Physiology of Organisms in Heavy Water, Journal of Medicine, Physiology and Biophysics, Vol. 10, pp. 71-109.

257. Ignatov, I., Mosin, O.V. (2015) Hydrothermal Conditions for Origin of Life and Living Matter, Journal of Health, Medicine and Nursing, Vol. 10, pp. 1-33.

258. Ignatov, I., Mosin, O.V. Velikov, B. (2015) Local Extremum at $8.95 \mu \mathrm{m}$ in Spectrum of Mountain Water as Indicator for Health and Longevity, Journal of Health, Medicine and Nursing, Vol. 10, pp.

259. Ignatov, I., Mosin, O.V. (2015) Electromagnetic Conception for the Eyesight in Additive Mixing of Colors, Journal of Health, Medicine and Nursing, Vol. 10, pp. 65-83.

260. Ignatov, I., Mosin, O.V. (2015) Water: Hydrogen Bonds. Nanostructures in Solid and Liquid Phases, Journal of Health, Medicine and Nursing, Vol. 10, pp. 84-110.

261. Ignatov, I., Mosin, O.V. (2015) Practical Implementation of Magnetic Water Treatment to Scaling Salts, Journal of Health, Medicine and Nursing, Vol. 10, pp. 111-125.

262. Ignatov, I., Gluhchev, G., Karadzhov, S., Miloshev, G., Ivanov, I., Mosin, O.V. (2015) Preparation of Electrochemically Activated Water Solutions (Catholyte/Anolyte) and Studying Their Physical-Chemical Properties, Journal of Medicine, Physiology and Biophysics, Vol. 11, pp. 1-21.

263. Ignatov, I., Mosin, O.V. (2015) Carbonaceous Fullerene Containing Mineral Shungite. Research of Influence of Shungite on Mountain Water, Journal of Medicine, Physiology and Biophysics, Vol. 11, pp. 2238.

264. Ignatov, I., Mosin, O.V. (2015) Electromagnetic Conception for the Eyesight. Explanation for what the People See Different Colors in Additive Mixing, Journal of Medicine, Physiology and Biophysics, Vol. 11, pp. 39-57.

265. Ignatov, I., Mosin, O.V. (2015) Hydrogen Bonds in Water. Nanostructures in Solid and Liquid Phases, Journal of Medicine, Physiology and Biophysics, Vol. 11, pp. 58-85.

266. Mosin, O.V., Ignatov, I. (2015) Magnetic Water Treatment for Elimination Scaling Salts, Journal of Medicine, Physiology and Biophysics, Vol. 11, pp. 86-100.

267. Gluhchev, G., Ignatov, I., Karadzhov, S., Miloshev, G., Ivanov, I., Mosin, O.V. (2015) Biocidal Effects of Electrochemically Activated Water, Journal of Health, Medicine and Nursing, Vol. 11, pp. 67-83.

268. Ignatov, I., Mosin, O.V. (2015) Nanoparticles of Microdispersed Colloid Silver. Practical Applications, Journal of Health, Medicine and Nursing, Vol. 11, pp. 84-94. 
269. Mosin, O.V., Ignatov, I. (2015) Isotopic Effects of Deuterium in Various Biological Objects as the Cells of Methylotrophic, Chemoheterotrophic, Photoorganotrophic Microorganisms and Green Algae, Journal of Health, Medicine and Nursing, Vol. 11, pp. 99-122.

270. Mosin, O.V., Ignatov, I., Skladnev, D. A., Shvets, V. I. (2015) The Biosynthesis of Deuterium Labeled Amino Acids using a Strain of Facultative Methylotrophic Bacterium Brevibacterium Methylicum 5662 with RuMP Cycle of Carbon Assimilation, European Journal of Molecular Biotechnology, Vol. 7, No.1, pp. 37-52.

271. Ignatov, I., Mosin, O.V. (2015) The Mathematical Model of Interaction of Carbonaceous Fullerene Containing Mineral Shungite and Microporous Crystalline Aluminosilicate Mineral Zeolite with Water, Nanotechnology Research and Practice, Vol. 5, No.1, pp. 23-36.

272. Ignatov, I., Mosin, O.V. (2015) Structural Mathematical Models of Water Clusters Regarding the Energy of Hydrogen Bonding, Nanotechnology Research and Practice, Vol. 5, No.1, pp. 37-56.

273. Ignatov, I., Mosin, O.V. (2015) Methods for Research of Mountain and Melt Water as Factor of Longevity. Chemical Composition, NES and DNES Methods for Spectral Analysis. Effects of Calcium, Magnesium, Zinc and Manganese, Advances in Physics Theories and Applications, Vol. 44, pp. 48-64.

274. Ignatov, I., Mosin,O.V. (2015) Research of Influence of Shungite for Activation of Mountain Water from Different Mountain Sources, Journal of Health, Medicine and Nursing, Vol. 12, pp. 1-18.

275. Ignatov, I., Mosin,O.V. (2015) Explanation for What the People See Different Colors in Additive Mixing. Electromagnetic Conception for the Eyesight, Journal of Health, Medicine and Nursing, Vol. 12, pp. 19-37.

276. Ignatov, I., Mosin,O.V. (2015) Modern Approaches for Practical Implementation of Magnetic Water Treatment to Eliminate Scaling Salts, Journal of Health, Medicine and Nursing, Vol. 12, 38-64.

277. Ignatov, I., Mosin,O.V. (2015) Research of Influence of Shungite on Mountain Water from Bulgaria. Mathematical Models of Water Influenced from Shungite and Zeolite, Journal of Medicine, Physiology and Biophysics, Vol. 12, pp. 1-18.

278. Ignatov, I., Mosin,O.V. (2015) Microdispersed Colloid Silver in Nanotechnologies, Journal of Medicine, Physiology and Biophysics, Vol. 12, pp. 19-30.

279. Ignatov, I., Mosin,O.V. (2015) Nanostructures in Solid and Liquid Phases of Water, Journal of Medicine, Physiology and Biophysics, Vol. 12, pp. 31-57.

280. Mosin,O.V., Ignatov, I. (2015) Cells of Methylotrophic, Chemoheterotrophic Microorganisms and Green Algae for the Research of Isotopic Effects of Deuterium, Journal of Medicine, Physiology and Biophysics, Vol. 12, pp. 58-81.

281. Mosin,O.V., Ignatov, I. (2015) Magnetic Water Treatment for Eliminate of Carbonate, Chloride and Sulfate Salts of $\mathrm{Ca} 2+, \mathrm{Mg} 2+, \mathrm{Fe} 2+$ and Fe3+ Cations, Journal of Medicine, Physiology and Biophysics, Vol. 12 , pp. 82-96.

282. Gluhchev, G., Ignatov, I., Karadzhov, S., Miloshev, G., Ivanov, I., Mosin, O. V. (2015) Studying of Virucidal and Biocidal Effects of Electrochemically Activated Anolyte and Catholyte Types of Water on Classical Swine Fever Virus (CSF) and Bacterium E. coli DH5, Journal of Medicine, Physiology and Biophysics, Vol. 13, pp. 1-17.

283. Ignatov, I., Gluhchev, G., Karadzhov, S., Miloshev, G., Ivanov, I., Mosin, O. V. (2015) Preparation of Electrochemically Activated Water Solutions (Catholyte/Anolyte) and Studying of their Physical-Chemical Properties, Journal of Medicine, Physiology and Biophysics, Vol. 13, pp. 18-38.

284. Ignatov, I., Mosin, O.V., Velikov, B. (2015) Isotopic Composition of Water as a Factor of Human Longevity, Journal of Medicine, Physiology and Biophysics, Vol. 13, pp. 36-67.

285. Mosin,O.V., Ignatov, I. (2015) The Metabolic Pathways of Biosynthesis of 2H-Labeled Purine Ribonucleoside Inosine by a Strain of Chemoheterotrophic Bacterium Bacillus Subtilis B-3157, Journal of Medicine, Physiology and Biophysics, Vol. 13, pp. 68-87.

286. Mosin,O.V., Ignatov, I. (2015) Methylotrophic Biomass as Substrate for Cultivation of Chemoheterotrophic Bacterium Bacillus Subtilis B-3157, Journal of Medicine, Physiology and Biophysics, Vol. 13, pp. 88-108.

287. Mosin,O.V., Ignatov, I. (2015) The Metabolic Pathways for Biosynthesis of 2H-Labaled Ribonucleoside Inosine by a Bacterium Bacillus Subtilis B-3157, Journal of Health, Medicine and Nursing, Vol. 13, pp. 49-63.

288. Ignatov, I., Gluhchev, G., Karadzhov, S., Miloshev, G., Ivanov, I., Mosin, O. V. (2015) Preparation of Electrochemically Activated Water Solutions (Catholyte/Anolyte) and Studying of their Physical-Chemical Properties, Journal of Health, Medicine and Nursing, Vol. 13, pp. 64-78.

289. Ignatov, I., Mosin, O.V. (2015) Metabolism, Physiology and Biotechnological Applications of Halobacteria, Journal of Health, Medicine and Nursing, Vol. 13, pp. 79-92.

290. Mosin,O.V., Ignatov, I. (2015) Deuterated Methylotrophic Biomass a Substrate for Microbiological 
Synthesis of 2H-Labeled Purine Ribonucleoside Inosine by Chemoheterotrophic Bacterium Bacillus Subtilis

B-3157, European Review of Chemical Research, Vol. 4, No. 4, pp. 87-103.

291. Ignatov, I., Mosin, O.V., Velikov, B. (2015) Isotopic Composition of Water as a Factor of Human Longevity in Research of Phenomenon of Longevity in Mountainous and Field Areas in Bulgaria, Journal of Pharmacy and Alternative Medicine, Vol. 4, pp. 36-56.

292. Ignatov, I., Mosin, O.V., Niggli, H., Drossinakis, Ch. (2015) Evaluation of Possible Methods and Approaches for Registering Non-Ionizing Radiation (NIR) Waves Emitting from the Human Body, Journal of Pharmacy and Alternative Medicine, Vol. 4, pp. 57-75.

293. Ignatov, I., Mosin, O.V. (2015) Some Aspects of Using Microdispersed Colloid Silver Nanoparticles in Medicine, Journal of Pharmacy and Alternative Medicine, Vol. 4, pp. 76-83.

294. Mosin,O.V., Ignatov, I. (2015) Microbiological Preparation of 2H-Labeled L-Phenylalanine with Different Levels of Isotopic Enrichment for Medical Diagnostics of Hereditary Phenylketonuria, Journal of Pharmacy and Alternative Medicine, Vol. 4, pp. 84-98.

295. Mosin,O.V., Ignatov, I. (2015) Studying Physiological, Cytological, and Morphological Changes of Prokaryotic and Eukaryotic Cells in Deuterium Oxide, Journal of Pharmacy and Alternative Medicine, Vol. 4, pp. 99-124.

296. Ignatov, I., Mosin, O. V., Gluhchev, G., Karadzhov, S., Miloshev, G., Ivanov, I., (2015) Studying Electrochemically Activated $\mathrm{NaCl}$ Solutions of Anolyte and Catholyte by Methods of Non-Equilibrium Energy Spectrum (NES) and Differential Non-Equilibrium Energy Spectrum (DNES), Journal of Medicine, Physiology and Biophysics, Vol. 14, pp. 6-18.

297. Mosin, O.V., Ignatov, I., (2015) Studying of the Heavy and Deuterium Depleted Types of Water on Biological Objects, ) Journal of Medicine, Physiology and Biophysics, Vol. 14, pp. 35-49.

298. Ignatov, I., Mosin, O.V. (2015) Studying Physical-Chemical Properties of Mountain Water from Bulgaria Influenced by a Fullerene Containing Mineral Shungite and Aluminosilicate Mineral Zeolite by IR, NES, and DNES Methods, Journal of Medicine, Physiology and Biophysics, Vol. 14, pp. 19-34.

299. Ignatov, I., Mosin, O.V. (2015) Metabolism and Physiology of Halobacteria, Journal of Medicine, Physiology and Biophysics, Vol. 14, pp. 65-78.

300. Mosin, O.V., Ignatov, I. (2015) Metabolism and Physiology of Methylotrophic Microorganisms, Journal of Medicine, Physiology and Biophysics, Vol. 14, pp. 50-64.

301. Ignatov, I., Mosin, O.V., Niggli, H., Drossinakis, H., Tyminski, G. (2015) Evaluation of Possible Methods and Approaches for Registering of Non-Ionizing Radiation Emitted from Human Body, European Journal of Medicine, Vol. 8, No.2, pp. 67-87.

302. Ignatov, I. Mosin, O.V. (2015) Research of Biophysical Influence on Model Systems from the Students of Walter Luebeck, Journal of Medicine, Physiology and Biophysics, Vol. 15, pp. 1-19.

303. Ignatov, I. Mosin, O.V. (2015) Studying the Hydrological Conditions for Origin of First Organic Forms of Life in Hot Mineral Water with HDO, Journal of Medicine, Physiology and Biophysics, Vol. 15, pp. 2041.

304. Ignatov, I. Mosin, O.V. (2015) Research of Mountain and Melt Water as Factor of Longevity. Effects of Calcium, Journal of Medicine, Physiology and Biophysics, Vol. 15, pp. 42-60.

305. Ignatov, I. Mosin, O.V. (2015) S. Miller's Experiments in Modelling of Non-Equilibrium Conditions with Gas Electric Discharge Simulating Primary Atmosphere, Journal of Medicine, Physiology and Biophysics, Vol. 15, pp. 61-76.

306. Ignatov, I. Mosin, O.V. (2015) The Improved Method for Isolation of Photochrome Transmembrane Protein Bacteriorhodopsin from Purple Membranes of Halobacterium Halobacterium Halobium ET 1001, Journal of Medicine, Physiology and Biophysics, Vol. 15, pp. 77-87.

307. Ignatov, I, Gluhchev, G., Karadzhov, S., Ivanov, N., Mosin, O.V. (2015) Preparation of Electrochemically Activated Water Solutions (Catholyte/Anolyte) and Studying Their Physical-Chemical Properties, Journal of Medicine, Physiology and Biophysics, Vol. 16, pp. 1-14.

308. Ignatov, I. Mosin, O.V. (2015) Physical-Chemical Properties of Mountain Water From Bulgaria Influenced by a Fullerene Containing Mineral Shungite and Aluminosilicate Mineral Zeolite, Journal of Medicine, Physiology and Biophysics, Vol. 16, pp. 15-29.

309. Ignatov, I. Mosin, O.V. (2015) Studying the Properties of Hot Mineral Water to Sustain the Organic Forms of Life by IR, NES and DNES Methods, Journal of Medicine, Physiology and Biophysics, Vol. 16, pp. 30-42.

310. Mosin, O.V., Ignatov, I. (2015) Evaluation of Possible Methods and Approaches for Magnetic Treatment of Water, Journal of Medicine, Physiology and Biophysics, Vol. 16, pp. 43-52.

311. Mosin, O.V., Ignatov, I. (2015) The Biological Adaptation to Deurerium Oxide. Phenotypic or Genotypic Phenomenon? Journal of Medicine, Physiology and Biophysics, Vol. 16, pp. 43-45.

312. Ignatov, I. Mosin, O.V., Bauer, E. (2015) Mathematical Model of Melt Water and Mountain Water 
from Bulgaria obtained by IR, NES and DNES-Methods, Journal of Medicine, Physiology and Biophysics, Vol. 17, pp. 30-52.

313. Ignatov, I., Mosin, O.V. (2015) Possible Processes for Origin of First Chemoheterotrophic Microorganisms with Modeling of Physiological Processes of Bacterium Bacillus Subtilis as a Model System in 2H2O, Journal of Medicine, Physiology and Biophysics, Vol. 17, pp. 53-75.

314. Ignatov, I. Mosin, O.V., Velikov, B. (2015) Isotopic Composition of Water as a Factor of Human Longevity in Research of Phenomenon of Longevity in Mountainious and Field Areas of Bulgaria, , Journal of Medicine, Physiology and Biophysics, Vol. 17, pp. 81-103.

315. Mosin, O.V., Ignatov, I. (2015) The Improved Method for Isolation of Photochrome Transmembrane Protein Bacteriorhodopsin from Purple Membranes of Halobacterium Halobacterium Halobium ET 1001, Journal of Medicine, Physiology and Biophysics, Vol. 17, pp. 104-114.

316. Ignatov, I. Mosin, O.V. (2015) Studying the Properties of Hot Mineral Water to Sustain the Organic Forms of Life by IR, NES and DNES Methods, Journal of Medicine, Physiology and Biophysics, Vol. 18, pp. 1-14.

317. Ignatov, I. Mosin, O.V. (2015) The Methods of Non-Equilibrium Spectrum (NES) and Differential Non-Equilibrium Spectrum (DNES) in Studying the Interaction of Carbonaceous Mmineral Shungite and Aluminosilicate Mineral Zeolite with Water, Journal of Medicine, Physiology and Biophysics, Vol. 18, pp. 15-31.

318. Mosin, O.V., Ignatov, I. (2015) Chromatographic Separation of Deuterium-Labeled Amino Acids, Proteins, Carbohydrates and Lipids Isolated From Bacterial Objects, Journal of Medicine, Physiology and Biophysics, Vol. 18, pp. 32-56.

319. Mosin, O.V., Ignatov, I. (2015) Introduction of Deuterated Aromatic Amino Acids [2,3,4,5,62H5]Phenylalanine, [3,5-2H2]Tyrosine and [2,4,5,6,7-2H5]Tryptophan Into a molecule of Photochrome Trans-Membrane Protein Bacteriorhodopsin, Journal of Medicine, Physiology and Biophysics, Vol. 18, pp. $57-73$.

320. Ignatov, I. Mosin, O.V. (2015) Results of Biophysical Research of Students of Christos Drossinakis, Journal of Medicine, Physiology and Biophysics, Vol. 18, pp. 74-92.

321. Ignatov, I. Mosin, O.V. (2015) Possible Processes for Origin of First Chemoheterotrophic Microorganisms with Modeling of Physiological Processes of Bacterium Bacillus subtilis as a Model System in 2H2O, European Journal of Molecular Biotechnology. Vol. 9, No. 3, pp. 131-155.

322. Gluhchev, G., , Ignatov, I., Karadzhov, S., Miloshev, G., Ivanov, N., Mosin, O.V. (2015) Electrochemically Activited Water: Biophysical and Biological Effects of Anolyte and Catholyte Types of Water, Vol. 7., No. 1, pp. 12-26.

323. Ignatov, I., Mosin, O.V., Bauer, E.(2015) Vortex Power Spring Water: Physical-Chemical Qualities of this Water compared to Mountain and Melt Water from Bulgaria, Russia and Glacier Rosenlaui from Swiss Alps, Advances in Physics Theories and Applications, Vol. 45, pp. 6-29.

324. Mosin, O.V., Ignatov, I., Skladnev, D. I., Shvets, V. I. (2015) The Development of Biosynthesis of 2Hand 13C-labeled Amino Acids and Proteins with Various Levels of Isotopic Enrichment Using Bacterial Objects, European Reviews of Chemical Research, Vol. 5., No. 3, pp. 144-165.

325. Ignatov, I., Mosin, O.V. (2015) Physical-Chemical Properties of Mountain Water from Bulgaria after Exposure to a Fullerene Containing Mineral Shungite and Aluminosilicate Mineral Zeolite, European Reviews of Chemical Research, Vol. 5., No. 3, pp. 166-179.

326. Ignatov, I., Mosin, O.V., Gluhchev, G., Karadzhov, S., Miloshev, G., Ivanov, N. (2015) The Evaluation of Mathematical Model of Interaction of Electrochemically Activated Water Solutions (Anolyte and Catholyte) with Water, European Reviews of Chemical Research, Vol. 2., No. 4, pp. 72-86.

327. Mosin, O.V, Ignatov, I. (2015) Deuterated Methylotrophic Biomass as a Substrate for Microbiological Synthesis of 2H-Labeled Purine Ribonucleoside Inosine by Chemoheterotrophic Bacterium Bacillus Subtilis B-3157, European Reviews of Chemical Research, Vol. 2., No. 4, pp. 87-103.

328. Ignatov, I., Mosin, O.V, Niggli, H., Drossinakis, Ch., Tyminsky, G. (2015) Methods for Registering Non-Ionizing Radiation Emitted from Human Body, European Reviews of Chemical Research, Vol. 1., No. 3, pp. 4-24. European Reviews of Chemical Research, Vol. 2, No. 4, pp. 4-24.

329. Gluhchev, G., Ignatov, I., Karadzhov, S., Miloshev, G., Ivanov, N., Mosin, O.V.(2015) Studying the Antimicrobial and Antiviral Effects of Electrochemically Activated Nacl Solutions of Anolyte and Catholyte on a Strain of E. Coli DH5 and Classical Swine Fever (CSF) Virus, European Journal of Medicine, Vol. 9., No. 3., pp. 124-138.

330. Ignatov, I., Mosin, O.V., Seidler, H. (2015) Registering of Electromagnetic Waves of the Human Body. Research with Various Model Physical Systems. Electric Activity of the Heart, Journal of Medicine, Physiology and Biophysics, Vol. 19., pp. 20-37.

331. Ignatov, I., Mosin, O.V. (2015) The Electron Microscopy of Micro-Dispersed Colloid Silver 
Nanoparticles, Journal of Medicine, Physiology and Biophysics, Vol. 19., pp. 38-46.

332. Ignatov, I., Mosin, O.V. (2015) Structural Models of Water and Structuring of Nano-clusters Regarding the Energies of Hydrogen Bonds, Journal of Medicine, Physiology and Biophysics, Vol. 19., pp. 47-65.

333. Mosin, O.V., Ignatov, I. (2015) Research the Influence of Deuterium Depleted and Heavy Types of Water on Biological Objects, Journal of Medicine, Physiology and Biophysics, Vol. 19., pp. 66-81.

334. Mosin, O.V., Ignatov, I. (2015) Isotope Purification of Drinking Water from Heavy Isotopes Deuterium (2H), Tritium (3H) and Oxygen (18O), Journal of Medicine, Physiology and Biophysics, Vol. 19., pp. 82-96.

335. Mosin, O.V., Ignatov, I. (2015) Isotope Purification of Drinking Water from Heavy Isotopes Deuterium (2H), Tritium (3H) and Oxygen (18O), Journal of Medicine, Physiology and Biophysics, Vol. 19., pp. 82-96.

336. Ignatov, I., Mosin, O.V. (2015) Physical-Chemical Properties of Mountain Water from Bulgaria after Exposure to a Fullerene Containing Mineral Shungite and Aluminosilicate Mineral Zeolite, European Reviewed of Chemical Research, Vol. 5, No. 3, pp. 143-172.

337. Ignatov, I., Mosin, O.V., Velikov, B., Bauer, E., Tyminski, G. (2015) Multifactorial Research of Longevity Phenomenon in Mountainous and Field Areas of Bulgaria, Russian Journal of Biological Research, Vol. 5, No. 3, pp. 124-143.

338. Mosin, O.V., Ignatov, I., Skladnev, D. I., Shvets, V. I. (2015) Studying Physiological. and Cytological Alterations in Prokaryotic and Eukariotic Cells in Heavy Water, Russian Journal of Biological Research, Vol. 5, No. 3, pp. 143-173.

339. Ignatov, I., Mosin, O.V. (2016) 2016-20 Years Scientific Research Center of Medical Biophysics, Journal of Medicine, Physiology and Biophysics, Vol. 20, pp. 24-42.

340. Ignatov, I., Mosin, O.V. (2016) Microdispersed Colloid Silver Nanoparticales: Studying and Properties, Journal of Medicine, Physiology and Biophysics, Vol. 20, pp. 6-12.

341. Ignatov, I., Mosin, O.V., Gluhchev, G., Karadzhov, S., Miloshev, G., Ivanov, I. (2016) Studying Electrochemically Activated $\mathrm{NaCl}$ Solutions of Anolyte and Catholyte by Methods of Non-Equilibrium Energy Spectrum (NES) and Differential Non-Equilibrium Energy Spectrum (DNES), Journal of Medicine, Physiology and Biophysics, Vol. 20, pp. 13-23.

342. Ignatov, I., Mosin, O.V. (2016) Studying the Composition and Properties of Mountain and Melt Water of Bulgaria and Russia as Factors of Longevity, Journal of Medicine, Physiology and Biophysics, Vol. 20, pp. 43-57.

343. Mosin, O.V., Ignatov, I. (2016) Alterations of Anatomy and Physiology of Organisms in Heavy Water, Journal of Medicine, Physiology and Biophysics, Vol. 20, pp. 58-84.

344. Ignatov, I., Mosin, O.V., Kirov, P. (2016) Mathematical Model of Kangen Water®. Biophysical and Biochemical Effects of Catholyte, Advances in Physics Theories and Applications, Vol. 51, pp. 33-55.

345. Krastev, D., Ignatov, I., Mosin, O. V., Penkov, P. (2016) Research on the Effects of the 'Dance of the Spiral' Methodology, with Spectral Analysis of Water Extracts, upon the Physiological Parameters of Plants and the Essential Oil Content, Advances in Physics Theories and Applications, Vol. 52, pp. 47-55.

346. Ignatov, I., Mosin, O.V., Velikov, B. (2016) Isotopic Composition of Water in Research into Phenomenon of Longevity in Mountainous and Field Areas of Bulgaria, Journal of Medicine, Physiology and Biophysics, Vol. 21, pp. 1-19.

347. Ignatov, I., Mosin, O.V. (2016) Studying the Composition and Properties of Mountain and Melt Water of Bulgaria and Russia as Factors of Longevity, Journal of Medicine, Physiology and Biophysics, Vol. 21, pp. 20-34.

348. Mosin, O.V., Ignatov, I. (2016) Studying the Influence of Heavy and Deuterium Depleted Types of Water on Biological Objects, Journal of Medicine, Physiology and Biophysics, Vol. 21, pp. 35-49.

349. Mosin, O.V., Ignatov, I. (2016) A Strain of a Gram-positive Chemoheterotrophic Bacterium Bacillus Subtilis B-3157 - producer of ${ }^{2} \mathrm{H}$-Labeled Purine Ribonucleoside Inosine, Journal of Medicine, Physiology and Biophysics, Vol. 21, pp. 50-65.

350. Ignatov, I., Mosin, O.V. (2016) Results of Bioinfluence of Dimitar Risimanski with Biophysical Model Systems, Journal of Medicine, Physiology and Biophysics, Vol. 24, pp. 5-17.

351. Ignatov, I., Mosin, O.V. (2016) Isotopic Composition, the Temperature and pH Value of Water in Experiments with Prognosis of Primary Hydrosphere and Possible Conditions for Origin of First Organic Forms in Hot Mineral Water with HDO, Journal of Medicine, Physiology and Biophysics, Vol. 24, pp. 1841 .

352. Ignatov, I., Mosin, O.V. (2016) The Reactions of Condensation-Dehydration Occurring in Aqueous Alkaline Solutions at $\mathrm{pH}=9-11$ and $\mathrm{t}=65-95^{\circ} \mathrm{C}$ in the Process of Modeling of Primary Hydrosphere, Journal of Medicine, Physiology and Biophysics, Vol. 24, pp. 42-55.

353. Ignatov, I., Mosin, O.V. (2016) Studying the Process of Formation of Precambrian Period Limestone 
Dolomite Fossils of Stromatolites in Hot Mineral Water Interacting with $\mathrm{CaCO}_{3}$, Journal of Medicine, Physiology and Biophysics, Vol. 25, pp. 29-44.

354. Ignatov, I., Mosin, O.V. (2016) Effects of Calcium, Magnesium, Zinc and Manganese in Water on Biophysical and Biochemical Processes in the Human Body, Journal of Medicine, Physiology and Biophysics, Vol. 25, pp. 45-63.

355. Ignatov, I., Mosin, O.V. (2016) New Evidence of the Existence of Associative Elements of Water (Clusters), Journal of Medicine, Physiology and Biophysics, Vol. 25, pp. 64-82.

356. Ignatov, I., Mosin, O.V. (2016) Biophysical Results of Research of People with Bioinformational Abilities from Bulgaria, Journal of Medicine, Physiology and Biophysics, Vol. 26, pp. 1-14.

357. Ignatov, I., Mosin, O.V. (2016) The Formation of Thermal Proteinoids in Hot Water, Journal of Medicine, Physiology and Biophysics, Vol. 26, pp. 15-27.

358. Ignatov, I., Mosin, O.V. (2016) Evaluation of Metabolic Pathways of Biosynthesis of L-Phenylalanine, Journal of Medicine, Physiology and Biophysics, Vol. 26, pp. 28-42.

359. Ignatov, I., Mosin, O.V. (2016) Biophysical Results of Bioinfluence of Dimitar Risimanski as Base of Medical Effects, Journal of Health, Medicine and Nursing, Vol. 27, pp. 24-35.

360. Ignatov, I., Mosin, O.V. (2016) Structural Alterations among Water Molecules after Bioinfluence of Dimitar Risimanski, Advances in Physics Theories and Applications, Vol. 57, pp.20-44.

361. Ignatov, I., Mosin, O.V. (2016) Studying the Composition and Properties of Mountain and Melt Water of Bulgaria and Russia as Factors of Longevity. Effect of Calcium, Magnesium, Zinc and Manganese in Water in Organism, European Journal of Molecular Biotechnology, Vol. 11, No. 1, pp. 13-28.

362. Krastev, D., Ignatov, I., Mosin, O.V., Penkov, P. (2016) Research of the Effects of the "Dance of the Spiral Metrology" upon the Physiological Parameters of the Plants and the Essential Oil Content, European Journal of Molecular Biotechnology, Vol. 11, No. 1, pp. 29-39.

363. Ignatov, I., Mosin, O.V., Bauer, E. (2016) Effects of Zinc and Manganese in Mountain and Glacier Water for Predominant Antioxidant Effects, Journal of Medicine, Physiology and Biophysics, Vol. 27, pp. 11-29.

364. Mosin, O.V., Ignatov, I. (2016) Heavy Water as Medium for Living Organisms, Journal of Medicine, Physiology and Biophysics, Vol. 27, pp. 62-88.

365. Ignatov, I., Mosin, O.V., Strommer, S. (2016) Nano Mix of Shungite and Zeolite for Cleaning of Toxins and Increasing of Energy of Hydrogen Bonds among Water Molecules in Human Body, Journal of Medicine, Physiology and Biophysics, Vol. 27, pp. 1-11.

366. Ignatov, I.et al. (2016) Results of Biophysical and Nano Technological Research of ZEOLITH Detox of LavaVitae Company, Journal of Health, Medicine and Nursing, Vol. 30. pp. 44-49.

367. Ignatov, I. (2016) Product of LavaVitae BOOST is Increasing of Energy of Hydrogen Bonds among Water Molecules in Human Body, Journal of Medicine, Physiology and Biophysics, Vol. 27., pp. 30-42.

368. Ignatov, I. (2016) VITA Intense - Proofs for Anti-inflammatory, Antioxidant and Inhibition Growth of Tumor Cells Effects. Relaxing Effect of Nervous System. Anti Aging Influence, Journal of Medicine, Physiology and Biophysics, Vol. Ignatov, I., Mosin, O.V., Velikov, B. (2016) Isotopic Composition of Water in Research into Phenomenon of Longevity in Mountainous and Field Areas of Bulgaria, Journal of Medicine, Physiology and Biophysics Vol. 22., pp. 1-19.

369. Ignatov, I., Mosin, O.V. (2016) Studying the Composition and Properties of Mountain and Melt Water of Bulgaria and Russia as Factors of Longevity, Journal of Medicine, Physiology and Biophysics Vol. 22., pp. 20-34.

370. Ignatov, I., Mosin, O.V. (2016) Studying the Influence of Heavy and Deuterium Depleted Types of Water on Biological Objects, Journal of Medicine, Physiology and Biophysics Vol. 22., pp. 35-49.

371. Mosin, O.V., Ignatov, I. (2016) A Strain of a Gram-positive Chemoheterotrophic Bacterium Bacillus Subtilis B-3157 - producer of 2H-Labeled Purine Ribonucleoside Inosine, Journal of Medicine, Physiology and Biophysics Vol. 22., pp. 35-49.

372. Ignatov, I., Mosin, O.V. (2016) Biochemical Results of Risimanski on Glucose Solution, Journal of Medicine, Physiology and Biophysics Vol. 28., pp. 1-11.

373. Ignatov, I., Mosin, O.V. (2016) Deuterium, Heavy Water and Origin of Life, LAP LAMBERT Academic Publishing, pp. 1-500.

374. Ignatov, I., Mosin, O.V. (2016) Water and Origin of Life, Altaspera Publishing \& Literary Agency Inc, pp. 1-616.

375. Ignatov, I., Mosin, O.V. (2016) New Nano- and Biotechnological Applications of Bacterial and Animal Photoreceptor Pigments-Bacteriorhodopsin, Rhodopsin and Iodeosin, Nanotechnology Research and Practice, Vol. 9, No. 1, pp. 12-28.

376. Mosin, O.V., Ignatov, I., Tyminski, G. (2016) Microbiological Synthesis of 2H- and 13C-Labbeled 
Amino Acids with Various Levels of Isotopic Enrichment by Methylotrophic Microorganisms, Questions of

Biological, Medical and Pharmaceutical Chemistry, Moscow, No.4, pp. 9-22.

377. Mosin, O.V., Ignatov, I. (2016) Evaluation of Biosynthetic Pathways of 2H-and 13C-Labeled Amino Acids by an Obligate Methylotrophic Bacterium Methylobacillus Flagellatum and a Facultative Methylotrophic Bacterium Brevibacterium Methylicum, European Journal of Molecular Biotechnology, Vol. 12, No. 2, pp. 58-76.

378. Gluhchev, G., Ignatov, I., Karadzhov, S., Miloshev, G., Ivanov, N., Mosin. O.V. (2016) Antimicrobial and Antiviral Effects of Electrolytic Water Solutions of Sodium Chloride (Anolyte/Catholyte) on a Strain of E. Coli and the Classical Swine Virus (CSF) Questions of Biological, Medical and Pharmaceutical Chemistry, Moscow, No.4, pp. 21-31.

379. Ignatov, I. (2017) Aluminosilicate Mineral Zeolite. Interaction of Water Molecules in Zeolite Table and Mountain Water Sevtopolis from Bulgaria, Journal of Medicine, Physiology and Biophysics, Vol. 31, pp. 41-45.

380. Ignatov, I. (2017) VITA intense and BOOST - Products with Natural Vitamins and Minerals for Health, Journal of Medicine, Physiology and Biophysics, Vol. 31, pp. 58-78.

381. Ignatov, I. (2017) ZEOLITH detox for Detoxification and ZELOLITH Creme for Skin Effects as Products of LavaVitae Company, Journal of Medicine, Physiology and Biophysics, Vol. 31, pp. 79-86.

382. Mehandjiev, D., Ignatov, I., Karadzhov, I., Gluhchev, G., Atanasov, A. (2017) On the Mechanism of Water Electrolysis, Journal of Medicine, Physiology and Biophysics, Vol. 31, pp. 23-26.

383. Ignatov, I., Mosin, O.V. (2016) Studying the Process of Formation of Precambrian Period Limestone Fossils of Stromatolites in Hot Mineral Water with CaCO3, Russian Journal of Biological Research, Vol. 8, No. 2, pp. 48-68.

384. Ignatov, I., Mosin, O.V. (2016) Can the First Organic Forms Of Life Originate in Hot Mineral Water with HDO? Russian Journal of Biological Research, Vol. 7, No. 1, pp. 4-19.

385. Ignatov, I., Mosin, O.V. (2016) Research of the Structural-Functional Properties of the Fullerene-Like Shungite and Micro-Crystalline Alumosilicate Mineral Zeolite by Elemental Analysis, TEM, IR and DNES Spectroscopy, Nano- and Microsystem Technique, Moscow, Vol. 18, No. 6, pp. 357-372.

386. Mosin, O.V., Ignatov, I., Shvets, V. I., Tyminski, G. (2016) Fast Atom Bombardment Mass Spectometry in Evaluation of Biosyntetic Pathways of Purine Ribonucleoside $\left[{ }^{2} \mathrm{H}\right]$ Inosine, Scientific Instrumentation, Vol. 26, No. 2, pp. 3-16.

387. Ignatov,I. (2017) Distribution of Molecules of ZEOLITH detox and ZEOLITH Creme in Water as Factor for Health, European Journal of Molecular Biotechnology, 5, No. 1, pp. 11-22.

388. Mehandjiev, D., Ignatov, I., Karadzhov, S., Gluhchev, G., Atanasov, A. (2017) Processes in Catholyte and Anolyte as Result of Water Electrolysis, European Journal of Molecular Biotechnology, 5, No. 1, pp. 23-29.

389. Ignatov, I. (2017) Research with Model Systems in Biophysics and Biochemistry of Bioinfluence of Dimitar Risimanski, European Journal of Medicine, Vol. 5, No. 2, pp. 43-55.

390. Gencheva, N., Angelcheva, M., Marinov, T., Ignatov, I. (2017) Assessment of Sportmanship in Case of Institutionalized Adolescents, Deprived of Parental Cares. Journal of Health, Medicine and Nursing, 103109.

391. Ignatov, I. (2017) Biophysical Research of ZEOLITH detox and ZEOLITH Creme of the Company LavaVitae, European Journal of Medicine, Vol. 5, No. 2, pp. 31-42.

392. Ignatov, I. (2017) Electromagnetic Conception for the Eyesight in Additive Mixing of Colors. Rhodopsin and Bacteriorhodopsin. Emotional Perception of Colors, Journal of Medicine, Physiology and Biophysics, Vol. 39, pp. 1-19.

393. Ignatov, I. (2017) VITA intense -Antioxidant and Inhibition Growth of Tumor Cells Effects. Anti Aging Influence. Negative Oxidation-reduction Potential (ORP) Has Important Role in These Effects, Journal of Medicine, Physiology and Biophysics, Vol. 39, pp. 20-42.

394. Ignatov, I. (2017) Moringa - Proofs for Anti-inflammatory, Antioxidant and Inhibition Growth of Tumor Cells Effects. Relaxing Effect of Nervous System and Effect on the Hypertonia, Journal of Medicine, Physiology and Biophysics, Vol. 39, pp. 43-56.

395. Marinov, T., Gencheva, N., Angelcheva, M., Ignatov, I., Dimitrov, V. (2017) Influence of Yoga Practices on Stress Coping Strategies, Journal of Medicine, Physiology and Biophysics, Vol. 39, pp. 57-63.

396. Ignatov, I. (2017) New Properties and Bio effects of High Quality Bulgarian Zeolite Rhodosorb-H®. and Cosmetic Water Rhodosorb-W®, Journal of Medicine, Physiology and Biophysics, Vol. 39, pp. 64-79.

397. Gluhchev, G., Mehandjiev, D., Ignatov, I., Karadzhov, S., Pesheva, Y., Atanasov, A. (2018) Water Electrolysis - Processes in Catholyte and Anolyte Results with Differential Non-equilibrium Water Spectrum, European Journal of Medicine, Vol. 6, No. 1, pp. 3-12.

398. Ignatov, I., Pesheva, Y.(2018) VITA intense - Product with Negative Oxidation-reduction Potential 
(ORP) as Important Quality for Antioxidant and Inhibition Growth of Tumor Cells Effects. Anti Aging

Effects, European Journal of Medicine, Vol. 6, No. 1, pp. 20-42.

399. Marinov, T., Gencheva, N., Angelcheva, M., Ignatov, I., Stefanova, D., Pesheva, Y. (2018) Aikido Game Activities as Stimulation Factor for a Proper Behavior in Conflict Situations, Vol. 6, No. 1, pp. 43-51.

400. Ignatov, I., Pesheva, Y. (2018) Rhodopsin. Bacteriorhodopsin in Biotechnology. Electromagnetic

Conception for the Eyesight, European Journal of Molecular Biotechnology, Vol. 6, No. 1, pp. 25-40.

401. Ignatov, I., Pesheva, Y. (2018) ZEOLITH Detox for Detoxification of Human Body. Proofs for Anti Inflammatory Effects of Zeolite and Detoxification, European Journal of Molecular Biotechnology, Vol. 6, No. 1, pp. 41-52.

402. Ignatov, I., Pesheva, Y. (2018) Studying of the Factors of Longevity in Smolyan Municipality, Rhodope Mountains, Bulgaria as Area of Oxidant/Antioxidant Balance, Journal of Natural Sciences Research, Vol 8, No 16 , pp. 29-42.

403. Ignatov, I. (2018) Qualitative Water for Quality Sport, XVIIIth Conference on Sports Medicine Sofia, Bulgaria

404. Ignatov, I. (2018) Research of the Factors of Health and Longevity of for the Population in Bulgaria, Bulgarian Journal of Public Health, Vol. 10, No. 3, pp. 52-65.

405. Ignatov, I. (2018) Mathematical Models of Spring Mountain Water from Bulgaria, International Conference on the Physics, Chemisry and Bioplogy of Water.

406. Bachev, V., Yaneva, I., Ignatov, I. (2018) Research of the Patients' Attitude in Their Use of Plant Products (Traditional Plant Medicinal Products, Plant Food Supplements, Teas) in Bulgaria, Journal of Medicine, Physiology and Biophysics, Vol. 51, pp. 1-9.

407. Ignatov, I., Akszjonovics, I. (2018) Biophysical Results with Influence of Device ABIEM on Model Systems. Bioharmonization, Journal of Medicine, Physiology and Biophysics, Vol. 51, pp. 10-30.

408. Ignatov, I., Denev, H. (2018) Results of Biophysical Research of People Educated by Methodic Vihriom, Journal of Medicine, Physiology and Biophysics, Vol. 51, pp. 31-56.

409. Ignatov, I. (2018)Biophysical and Biochemical Results of the Product from Bulgaria Gift from Garabitov ${ }^{\circledR}$, Journal of Medicine, Physiology and Biophysics, Vol. 51, pp. 57-67.

410. Bachev, V., Yaneva, I, Georgiev, S., Ignatov, I. (2018) Ten Plant Species Most Commonly Used in the Form of Tea and Plant Food Supplements in Bulgaria, Journal of Medicine, Physiology and Biophysics, Vol. 51, pp. 68-74.

411. Ignatov, I., Karadzhov, S., Gluhchev, G., Yakimov, I. (2018) Electromagnetically Activated Water Properties and Effects, Bulgarian Journal of Public Health, 10 (4): 63-69.

412. Marinova, D., Angelcheva, M., Marinov, M., Ignatov, I. (2019) Influence of Tuina Therapy on Pain as Regards Quality of Life Among Patients Suffering from Multiple Sclerosis, Journal of Medicine, Physiology and Biophysics, Vol. 52, pp. 1-6.

413. Gencheva, N, Angelcheva, M., Marinov, T., Ignatov, I. (2019) Research of the Emotianal Inteligence of Bulgarian Physiotherapy Students, Journal of Medicine, Physiology and Biophysics, Vol. 52, pp. 12-19.

414. Vassileva, P., Voykova, D., Ignatov, I., Karadzhov, S., Gluhchev, S., Ivanov, N., Mehandjiev, D. (2019) Results from the Research of Water Catholyte with Nascent (Atomic) Hydrogen, Journal of Medicine, Physiology and Biophysics, Vol.52, pp. 7-11.

415. Ignatov, I., Toshkova, R., Gluhchev, G.\&Drossinakis, Ch. (2019) Results of Blood Serum from Cancer Treated Hamsters with Infrared Thermal Field and Electromagnetic Fields, Journal of Health, Medicine and Nursing, Vol. 58, pp. 101-112.

416. Ignatov, I., Gluhchev, G, (2019) Effects of Electrochemically Activated Water Catholyte and Anolyte on Human Health, 8th World Congress on Immunology, Pulsus, London, Vol. 3, pp. 12-13. Drossinakis, Ch., Toshkova, R., Zvetkova, E, Ignatov, I,.\&Gluhchev, G. (2019) Methods of Research in Vivo Research of Therapeutical Effect in Hamsters with Experimental Myeloid Tumor of Graffi, 8th World Congress on Immunology, Pulsus, London, Vol. 3, pp. 21.

417. Toshkova, R., Ignatov, I., Zvetkova, E., Gluhchev, G., Drossinakis, Ch. (2019) Bioinfluence with Infrared Thermal and Electromagnetic Fields as a Therapeutic Approach of Hamsters with Experimental Graffi Myeloid Tumor, Journal of Natural Sciences Research, Vol. 9 No 4, pp. 1-11.

418. Toshkova, R.; Ignatov, I.; Zvetkova, E.; Gluhchev, G.; Drossinakis, Ch. (2019) Beneficial Effects of Drossinakis Bio-influence (With Infrared Thermal and Electromagnetic Fields) on the Development of Experimental Graffi Myeloid Tumors in Hamsters. Hematological Studies, Journal of Medicine, Physiology and Biophysics, Vol. 54, pp.13-17.

419. Gluhchev, G., Ignatov, I., Karadzhov, S., Miloshev, G., Ivanov, N., Mosin, O.V. (2016) Antimicrobial and Solutions Antiviral Effects of Electrolytic Water Solutions of Sodium Chloride (Anolyte/Catholyte) on a Strain of E. Coli DH5 and the Classical Swine Fever Virus (CSF), Problems of Biological, Medical and Pharmaceutical Chemistry, No. 1, pp. 21-31. 
420. Yakimov, I., Ignatov, I. (2019) Hydration and Properties of Water in Football for Excellent Shape, Int. Conference on Medicine and Football, Sofia, Bulgaria, Journal of Medicine and Sport, pp. 46-51.

421. Ignatov, I., Drossinakis, Ch., Toshkova, R., Zvetkova, E., Gluhchev, G. (2019) Effects of Electromagnetic Fields over DNA in Tumor Diseases, Biophysical and Biochemical Model Systems, Journal of Medicine, Physiology and Biophysics, Vol. 56, pp. 11-20.

422. Drossinakis, Ch., Ignatov, I. (2019) Biological Effects of Christos Drossinakis on Model Bio Systems with Cancer Cells, Journal of Nursing and Health Care, Vol. 4, No 2, pp. 1-2.

423. Toshkova, R., Ignatov, I., Zvetkova, E., Gluhchev, G. (2019) Effects of Catholyte Water on the Development of Experimental Graffi Tumor on Hamsters, Cells\&Cellular Life Sciences Journal, Vol. 4, No.1, 000140

424. Toshkova, R., Ignatov, I., Zvetkova, E., Gluhchev, G. (2019) Effects of Catholyte Water on the Development of Experimental Graffi Tumor on Hamsters, European Journal of Medicine, Vol. 7 No 1, pp. 45-56.

425. Ignatov, I. (2018) Carbonaceous Fullerene Containing Nano Mineral Shungite. Propertiesfor Purification of Water Detoxification of Human Body Nanotechnology Research and Practice, Vol.5, No.1, pp, 3-13.

426. Ignatov, I., Toshkova, R., Zvetkova, E., Gluhchev, G. (2019) Research of Catholyte Water on Experimental Graffi Tumor on Hamsters. Kangen Device for Catholyte Water, Cancer Stem Cell, Epidemiology and Surgery, Seoul. pp. 25

427. Drossinakis, Ch., Ignatov, I., Toshkova, R., Zvetkova, E., Gluhchev, G. (2019) Functional Changes of Cells and DNA by Electromagnetic Waves in the Case of Cancer, Cancer Stem Cell, Epidemiology and Surgery, Seoul. pp. 23

428. Ignatov, I., Toshkova, R., Zvetkova, E., Gluhchev, G. (2019) Research of Catholyte Water on Experimental Graffi Tumor on Hamsters. Kangen Device for Catholyte Water, Journal of Medicine, Physilogy and Biophysics, Journal of Medicine, Physilogy and Biophysics, Vol. 59, pp. 1-9

429. Valcheva. N., Ignatov, I. (2019) Physicochemical and Microbiological Characteristics of Thermal Healing Spring Waters in the District of Varna, , Journal of Medicine, Physilogy and Biophysics, Vol. 59, pp. 10-16.

430. Ignatov, I., Drossinakis, Ch., Toshkova, R., Zvetkova, E., Yaneva, I., Gluhchev, G. (2019) Effects of Electromagnetic Fields over DNA Hydrogen Bonds of Hamsters with Implanted Graffi Tumor, European Journal of Medicine, Vol. 7, No 2, pp. 92-98.

431. Ignatov, I., Mehandjiev, D., Vassileva, P., Voykova, D., Karadzhov, S., Gluhchev, G., Ivanov, N. (2019) Research of Water Catholyte of Presence of Nascent (Atomic) Hydrogen ( $\left.\mathrm{H}^{*}\right)$. Hydrogen and Nascent Hydrogen of the Reactions for Origin of Life in Hot Mineral Water, European Journal of Medicine, 2019, Vol. 7, No 2, 99-105.

432. Ignatov, I. (2019) Electrochemically Activated Water Catholyte for Activation of Shape and Recovery in the Sport, Int. Conference on Medicine and Football, Sofia, Bulgaria, Journal of Medicine and Sport, No. $3-4, \mathrm{pp}$

433. Ignatov, I., Drossinakis, Ch., Toshkova, R., Zvetkova, E., Yaneva, I./, Gluhchev, G. (2019) Effects of Electromagnetic Fields over DNA of Hamsters with Implanted Graffi Tumor, Journal of Health, Medicine and Nursing, Vol. 68., pp. 34-40.

434. Toshkova, R., Zvetkova, E., Ignatov, I., Gluhchev, G. (2019) Effects of Catholyte Water on the Development of Experimental Graffi Tumor on Hamsters, Bulgarian Journal of Public Health, Vol. 11, No. 3, pp. 60-73.

435. Ignatov, I. (2019) Origin of Life in Hot Mineral Water from Hydrothermal Springs and Ponds. Effects of Hydrogen and Nascent Hydrogen. Analyses with Spectral Methods, pH and ORP, European Reviews of Chemical Research, Vol. 6, No. 2, pp. 49-60.

436. Ignatov, I., Toshkova, R.,Gluhchev, G., Zvetkova, E. (2019) Results with IR Spectroscopy of CortiNon+ on the Development of Experimental Graffi Tumor on Hamsters, European Reviews of Chemical Research, Vol. 6, No. 2, pp. 61-67.

437. Ignatov, I., Vanlyan, K. (2020) Electromagnetic Conception of Color Vision in Additive Mixing of Colors. Application in the Photography. Art and Psychology, Journal of Medicine, Physiology and Biophysics, Vol. 64, pp. 9-13.

438. Ignatov, I., (2020) Health Status as Result of Analyses of Parameters of Hydrogen Bonds Among Water Molecules in Human Body. Entropy in Living Organisms, Journal of Medicine, Physiology and Biophysics, Vol. 64, pp. 14-20.

439. Valcheva, N., Ignatov, I., Dinkov, G. (2020) Microbiological and Physicochemical Research of Thermal Spring and Mountain Spring Waters in the District of Sliven, Bulgaria, Journal of Advances in Microbiology,Vol. 20, No.2, pp.9-17. 
440. Ignatov, I., Gluhchev, G., Karadzhov, G., Yaneva, I., Valcheva, N., Dinkov, G,, Popova, T., Petrova, T., Mehandjiev, D., Akszjonovich, I. (2020) Dynamic Nano Clusters of Water on Waters Catholyte and Anolyte: Electrolysis with Nano Membranes, Physical Science International Journal. Vol. 24, No.1, pp. 4654.

441. Ignatov, I. (2019) Spectral Analyses of Water ADVA. Biophysical, Biochemical and Biological Effects, European Journal of Molecular Biotechnology, Vol. 7, No.2, pp. 86-90.

442. Karadzhov, S., Ignatov, I., Najdenski, H., Popova, T., Luepcke, W., Gluhchev, G., Kolev, N., Balabanov, S. (2019) Distribution Trends of African Swine Fever Virus (ASFV) through Water, European Journal of Molecular Biotechnology, Vol. 7, No. 2, pp. 123-125.

443. Ignatov, I., Gencheva, N., Marinov, T., Yaneva, I., Angelcheva, M., Dinkov, G., Angushev, I. (2020) Electrochemically Activated Water Catholyte for the Activation of Hydrogen Ions and ATP for Sport's Shape and Recovery, Journal of Advances in Medicine and Medical Research, 32 (4): 112-119.

444. Ignatov, I., Valcheva, N. (2020) Microbiological and Physicochemical Research of Mountain Spring Waters in Vasiliovska Mountain, Municipality of Teteven, Bulgaria, Chemical Science International Journal, Vol.29, No.3,pp.16-23.

445. Popova, T., Petrova, T., Ignatov, I., Karadzhov, S. (2020) Preliminary In Vitro Investigations on The Inhibitory Activity of The Original Dietary Supplement Oxidal ${ }^{\circledR}$ On Pathogenic Bacterial Strains, Journal of Advances in Agriculture, 11: 37-43.

446. Ignatov, I. (2020) Antiviral Effects of Nano Colloidal Silver, Water Catholyte, Oxidal with Methylene Blue. Possible Effects of Influence over Coronavirus SARS-CoV and SARS-CoV-2 with Disease COVID19, Global Congress on Infectious Diseases, SciTech Infectious Diseases 2020.

447. Valcheva, N., Ignatov, I., Mihaylova, S. (2020) Physiological and Molecular-genetic Characteristic of Bacteria Strains, Isolated from Mountain Spring and Mineral Waters in Plovdiv Region, Bulgaria, International Journal of Pathogen Research, Vol. 4, No. 1, pp. 44- 55.

448. Ignatov, I. (2020) Antibacterial and Antiviral Effects of Water Catholyte, Oxidal with Methylene Blue and Colloidal Silver, Journal of Medicine, Physiology and Biophysics, Vol. 65, pp. 26-31.

449. Popova, T., Petrova, T., Ignatov, I., Karadzhov, S., Dinkov, G., Antibacterial Activity of the Original Dietary Supplement Oxidal ${ }^{\circledR}$ in Vitro, Journal of Advances in Agriculture, 2020; 11: 71-78.

450. Ignatov, I. (2020) Antiviral Effects of Water Catholyte, Oxidal with Methylene Blue and Colloidal Silver. Possible Mechanism of Influence over Coronavirus SARSr-CoV and SARSr-CoV-2 with Disease COVID-19, Journal of Health, Medicine and Nursing, Vol. 73, pp. 96-101.

451. Ignatov, I. (2020) Antiviral Effects of Water Catholyte, Oxidal with Methylene Blue and Colloidal Silver. Possible Mechanism of Influence over Coronavirus SARSr-CoV and SARSr-CoV-2 with Disease COVID-19, Journal of Infectious Diseases and Research, Vol. 3, issue S1.

452. Toshkova, R., Ignatov, I., Zvetkova, R., Gluhchev, G., Dinkov, G.(2020) In vivo Effects of CortiNon+ on the Emergence and Progression of Experimental Graffi Tumor in Hamsters, International Research Journal of Oncology, Vol. 3 No.1, pp. 27-36.

453. Todorova, T., Dimitrov, M., Ignatov, I., Gluhchev, G., Dinkov, G. (2020) Oxidal® Ameliorates the Ty1 Retrotransposition Induced by Methyl Methanesulfonate in Saccharomyces cerevisiae, Microbiology Research Journal International, Vol. 30, No. 4, pp. 34-42.

454. Ignatov, I. (2020). Anti Inflammatory and Anti Viral Effects of Potassium (K) and Chemical Composition of Moringa. Asian Journal of Biology, Vol. 9, No. 2, pp. 1-7.

455. Mehandjiev, D., Gluhchev, G., Ignatov, I., Vassileva, P., Voykova, D., Ivanov, N. (2020) Electrochemically Activated Water - Anolyte. Nascent Oxygen, International Research Journal of Pure and Applied Chemistry, Vol. 21, No. 9, pp. 78-82.

456. Ignatov. I., Gluhchev. G., Huether, F. (2020) Dynamic Nano Clusters of Water on EVODROP Water, Physical Science International Journal, Vol. 24, No.7, pp. 47-53.

457. Ignatov, I. (2020) Applications of EVODROP Water as Drinking Water of Highest Quality and EVOhygiene Colloidal Silver and Cooper Nano Water. Antibacterial and Antiviral Effects that also Help to Combat SARS-CoV-2, Scientific Research Center of Medical Biophysics.

458. Ignatov, I.,Mosin, O.V.(2016) Water and Origin of Life: Collection of Scientific Publications, Moscow, Berlin, Direct Media, pp. 1-658.

459. Valcheva, N., Ignatov, I. (2020). Microbiological Research of the Effects of Electromagnetic Fields of the Bacteria Escherichia coli, Enterococci, Coliforms and Clostridium perfringens, Microbiology Research Journal International, Vol. 30, No. 9, pp. 39-44.

460. Yaneva, I., Balabanski, V., Karanesheva, T., Ignatov, I. (2020) Some Endangered Healings Plants in Bulgaria - Legislative Regulation, Protection, Characteristic description, Application, Agricultural cultivation, Bulgarian Journal of Agricultural Science, Vol. 26, No. 4, pp. 847-852.

461. Ignatov, I., Drossinakis, Ch. (2020). Effects of Electromagnetic Fields on Colloidal Nano Silver for 
Applications in Nano Medicine. Advances in Research, Vol. 21, No.11, 20-27.

462. Valcheva, N., Ignatov, I., Huether, F. (2020). Microbiological Research of the Effects of EVODROP Silver Nanoparticle on Escherichia coli, Enterococci and Coliforms. Journal of Advances in Microbiology, Vol. 20, No.11, pp. 22-31.

463. Ignatov, I., Valcheva, N., Huether, F. (2020). Nano and Microbiological Effects of EVODROP Silver and Copper Nanoparticle. Journal of Materials Science Research and Reviews, Vol. 6, No. 4, pp. 63-71.

464. Review - Scientific Publications of Prof. Ignat Ignatov from 2000 to 2020; Special issue of Scientific Research Center of Medical Biophysics.

465. Prof. Christos Drossinakis - Scientific Publications from 2000 to 2020; IAWG- Special issue of INTERNATIONALE Akademie für Wissenschaftliche Geistheilung.

466. Ignatov, I. (2020) Microbiological Research of Mineral and Mountain Spring Waters in Bulgaria, Microbiology Research Journal International, Vol. 30, No.10, pp. 79-84.

467. Ignatov, I. (2021). Standards for the Research and Registration of Drinking Mineral and Mountain Spring Waters in Bulgaria. Asian Journal of Chemical Sciences, Vol. 9, No.1, pp. 12-18.

468. Ignatov, I., Valcheva, N., Mihaylova, S., Dinkov, G. (2020) Physicochemical and Microbiological Results of Hyperthermal (Hot) Mineral Water in Rupite, Bulgaria as Model System for Origin of Life. Uttar Pradesh Journal of Zoology, Vol. 41, No. 24, pp. 16-22.

469. Ignatov, I.(2020) Physicochemical Research of Mineral and Mountain Spring Waters in Bulgaria, Asian Journal of Applied Chemistry Research, Vol. 7, No.2. pp. 40-46.

470. Ignatov, I., Valcheva, N. (2021) Physiological and Molecular Characteristics of Bacillus spp. Isolated from Warm Mineral Waters in Varna, Bulgaria as Model System for Origin of Life, Uttar Pradesh Journal of Zoology, Vol. 42, No. 1, pp. 51-58.

471. Popova, T., Ignatov, I., Petrova, T., Dinkov, G. (2021) Antimicrobial Activity of Pregnenolone in vitro, Journal of Pharmaceutical Research International, Vol. 33, No.1, pp. 61-67.

472. Ignatov, I., Popova, T. (2021) Applications of Moringa oleifera Lam., Urtica dioica L., Malva sylvestris L. and Plantago major L. Containing Potassium for Recovery, Plant Cell Biotechnology and Molecular Biology Journal, Vol. 22, No 7-8, pp. 93-103.

473. Huether, F., Ignatov, I., Valcheva, N., Gluhchev, G. (2020) Applications of EVODROP Water as Drinking Water of Highest Quality. Antibacterial and Antiviral Effects of EVOhygiene Colloidal Silver and Cooper Nano Water, European Journal of Molecular Biotechnology, Vol. 8, No 1, pp. 14-23.

474. Ignatov, I. (2020) Origin of Life in Hot Mineral Water. Analyses with Infrared Spectral Methods, pH and ORP. Effects of Hydrogen and Nascent Hydrogen, European Journal of Molecular Biotechnology, Vol. 8, No 1, pp. 14-23.

475. Toshkova, R., Ignatov, I., Gluhchev, G., Dinkov, G. (2021) Protective and Antitumor Effects of Oxidal and Pyrucet in Hamsters with Experimental Graffi Tumor, Journal of Pharmaceutical Research International, Vol. 33, No. 12, pp. 1-19.

476. Ignatov. I., Angelcheva, M., Angushev, I. (2021) Doses of $\mathrm{Ca}^{2+}, \mathrm{Mg}^{2+}, \mathrm{K}^{+}, \mathrm{Na}^{+}, \mathrm{Mn}^{2+}$ and $\mathrm{Zn}^{2+}$ in Mountain Spring and Mineral Waters in Hydration Reaction During Sport Training and Recovery; Combination with Vitamins, Journal of Pharmaceutical Research International, Vol. 33, No. 16, pp. 76-85.

477. Ignatov, I. (2021) Origin of Life and Living Matter in Hot Mineral Water and Properties of Polar Molecules in the Primary Hydrosphere and Hydrothermal Ponds, Uttar Pradesh Journal of Zoology, Vol. 42 No. 6, pp. 37-52. 